FEDERAL RESERVE BANK OF SAN FRANCISCO

WORKING PAPER SERIES

\title{
The international dimension of US expansions: A structural VAR analysis
}

\author{
Giancarlo Corsetti \\ European University Institute, \\ University of Rome III, and CEPR \\ Luca Dedola \\ European Central Bank and CEPR \\ Sylvain Leduc \\ Federal Reserve Bank of San Francisco
}

October 2008

Working Paper 2007-27

http://www.frbsf.org/publications/economics/papers/2007/wp07-27bk.pdf

The views in this paper are solely the responsibility of the authors and should not be interpreted as reflecting the views of the Federal Reserve Bank of San Francisco or the Board of Governors of the Federal Reserve System. This paper was produced under the auspices of the Center for Pacific Basin Studies within the Economic Research Department of the Federal Reserve Bank of San Francisco. 


\title{
The international dimension of US expansions: A structural VAR analysis $^{1}$
}

\author{
Giancarlo Corsetti \\ European University Institute, University of Rome III and CEPR \\ Luca Dedola \\ European Central Bank and CEPR \\ Sylvain Leduc \\ Federal Reserve Bank of San Francisco
}

This draft: October 2008

\begin{abstract}
${ }^{1} \mathrm{~A}$ previous version of this paper was circulated under the title "Productivity and the dollar". We thank our dicussants Emmanuel Farhi and Silvana Tenreyro, as well as Fabio Canova, Larry Christiano, Martin Eichenbaum, Fabio Ghironi, Wouter den Haan, Andrea Raffo, Sergio Rebelo, Martin Uribe and seminar participants at the Bank of Canada, Duke University, ECB, ESSIM 2007, the Federal Reserve Bank of Australia, the Federal Reserve Bank of San Francisco Pacific Basin conference, the Federal Reserve Bank of New York, the Federal Reserve Board, Georgetown University, MIT, the NBER Summer Institute 2007, Ohio State University, the University of Aix-Marseille II, University of Amsterdam, University of Lausanne, and University of Zurich for useful comments. We are grateful to Flavia Corneli and Lenno Uusküla for outstanding research assistance. Corsetti's work on this paper is part of the Pierre Werner Chair Programme on Monetary Union, at the Robert Schuman Centre of the European University Institute. The views
\end{abstract}




\begin{abstract}
This paper investigates the international dimension of productivity and demand shocks in the US using sign restrictions based on standard theory predictions. Identifying shocks to US manufacturing - our measure of tradables - we find that productivity gains have substantial aggregate demand effects, boosting US consumption and investment, relative to the rest of the world, thus raising real imports; net exports and US net foreign assets correspondingly decrease. At the same time, however, these shocks appreciate the US real exchange rate, improve the terms of trade and raise stock prices. Shocks to the demand for US manufacturing appear to have less pronounced aggregate effects, with little impact on trade and capital accounts; they lead to a (delayed) dollar appreciation, however. Our findings provide novel evidence on key channels of the international transmission of shocks, pointing to a low degree of consumption risk sharing as an essential feature of the transmission mechanism, and suggesting that strong wealth effects play an important role in generating aggregate demand fluctuations across countries.

JEL classification: F32, F41, F42

Keywords: International transmission mechanism, terms of trade, real exchange rates, VAR, sign restrictions, US current account.
\end{abstract}

expressed here are those of the authors and do not necessarily reflect the positions of the ECB, the Board of Governors of the Federal Reserve System, or any other institutions with which the authors are affiliated. 


\section{Introduction}

What are the consequences of shocks bringing about an economic expansion in the United States for variables shaping its international dimension, such as the real value of the dollar, US trade flows and International Investment Position, as well as the relative value of US assets? A widespread view in policy and market circles is that a US expansion, associated with consumption, investment, and possibly stock market booms, leads to real dollar appreciation, and a deterioration of the external balance. This view appears to fit well important recent episodes of high US output and productivity growth, accompanied by large upward swings in the dollar real exchange rate and current account deficits. ${ }^{1}$ Intriguing empirical evidence consistent with it is also provided by several studies documenting that positive surprises about the US business cycle tend to strengthen the US currency, negative ones to weaken it - e.g., see Andersen et al. [2003] and the recent survey by Engel et al. [2007].

This popular view is typically associated with traditional models that stress real demand disturbances and their transmission via competitiveness channels — such as the Mundell-Fleming-Dornbusch (MFD) framework. In this framework, a real demand increase appreciates the currency in nominal and real terms, thus crowding out net exports. As explicitly recognized by Dornbusch [1980], however, the MFD framework does not account for endogenous wealth and demand effects in the international transmission. ${ }^{2}$ By adopting an explicit intertemporal utility maximization framework to endogenize these effects, the same popular view can indeed be articulated coherently with modern open-economy theory, stressing different structural shocks and tracing their propagation through endogenous demand movements in general equilibrium - demand and wealth effects obtain via a variety of real and fi-

\footnotetext{
${ }^{1}$ On average, US cyclical output and consumption expansions are indeed positively correlated with trade deficits, real exchange rate appreciation and terms of trade improvement, a point implied by the findings by Backus and Smith [1993] and Corsetti, Dedola and Leduc [2008].

${ }^{2}$ This issue is at the heart of the debate on the Harberger-Laursen-Metzler effect, revolving around the relationship between aggregate spending, the current account and the terms of trade - see e.g. Obstfeld [1982] and Svensson and Razin [1983]. In the words of the former author, "Laursen and Metzler adopted the Keynesian assumption" of a stable relationship between current real income and consumption, arguing that "a deterioration of the terms of trade, which lowers real income, must lower saving as well," resulting in a current account deficit. (Obstfeld [1982], pp. 251-252)
} 
nancial channels, including the dynamics of saving and investment, relative prices, asset returns and portfolio allocation.

While there are many empirical studies characterizing the US and the international business cycles, relatively little work has been devoted to structural investigations of the international dimension of US business cycle impulses, with the exception of monetary and fiscal policy shocks. ${ }^{3}$ Structural studies emphasizing other important drivers of the business cycles are clearly needed to shed light on specific aspects of the transmission mechanism, and to provide guidance on the empirical content of different theories.

As a contribution towards this goal, this paper documents the effects of productivity and demand shocks in the United States on a broad range of internal and external macroeconomic variables: absorption, trade, international relative prices, asset prices and foreign asset positions. Using structural VARs, we identify productivity and demand shocks via the sign-restriction methodology adopted by Canova and De Nicoló [2002], Uhlig [2005], and Dedola and Neri [2007]. Namely, we impose intuitive, theory-based restrictions, consistent with a large class of models, on the sign of the impulse responses of a small subset of variables. Our focus is deliberately on shocks to US manufacturing relative to manufacturing in the rest of the industrial world. Since manufactures account for a large share of international trade, they arguably play a key role in shaping macroeconomic interdependence across countries. Most importantly, we take advantage of the fact that theory's predictions are quite clear-cut for shocks hitting tradables. As discussed in Section 2, focusing on manufacturing facilitates identification, and avoid potentially difficult issues in the interpretation of the results.

Our estimates show that productivity shocks to US manufacturing have significant effects on US aggregate demand: consistent with the predictions of the intertemporal-trade approach to the current account, they persistently increase US aggregate consumption and investment relative to the rest of the world, raising imports and worsening the US trade balance - the trade deficit turns out to be quite long-lasting. Most interestingly, productivity shocks cause real appreciation, rather than depreciation, in all our measures of the international relative prices of US goods, namely, a CPI-based, a PPIbased and an export-deflator-based real exchange rate - the latter being

\footnotetext{
${ }^{3}$ Using structural VAR methods, an important and extensive literature analyzes the open economy effects of US policy shocks, both monetary (e.g. Eichenbaum and Evans [1995], and Kim and Roubini [2005], among others) and fiscal (Kim and Roubini [2008] and Corsetti and Muller [2006], among others).
} 
constructed to proxy for bilateral terms of trade. In other words, the real dollar appreciation triggered by a positive productivity shock to tradables is not exclusively due to a rise in the relative price of US nontradablesaccording to the classical Harrod-Balassa Samuelson effects - , but also to an improvement in the US terms of trade. Note that, in line with Engel [1999], these findings imply that movements in traded goods prices are major drivers of the dollar real exchange rate.

Productivity shocks also raise the value of the US stock market relative to an aggregate index of foreign markets - between 2 to 7 percent; they open a positive nominal interest differentials in favor of the US over time, with a delay of a few quarters. Using the series of valuation-adjusted US Foreign assets and liabilities computed by Gourinchas and Rey [2007], we find that in addition to deteriorating net trade, asymmetric productivity gains worsen the US net foreign asset position relative to GDP. Most notably, the fall in US net foreign wealth corresponds to an increase in both gross assets and gross liabilities, also relative to GDP. The increase in gross foreign assets in dollar terms is intriguing, in light of the finding that the exchange rate appreciates. As most of the US foreign assets are denominated in foreign currency, a dollar appreciation tends to reduce the relative value of outstanding assets: the rise of this stock must be then driven by some combination of capital gains in foreign currency, and positive purchases by US residents.

Concerning demand shocks to US manufacturing, we find that they typically have the expected qualitative effects, but, quantitatively, tend to be not very consequential for macroeconomic dynamics. In response to a relative increase in demand for US manufacturing, all US international relative prices strengthen, though only with some delay; aggregate investment rises, although by less than in response to productivity shocks. The effects on consumption, trade balance, gross and net external asset positions, stock prices and interest differentials are all subdued.

Overall, these findings square quite well with the market and policy view of the international dimension of US favorable shocks. At the same time, however, they provide novel evidence on key channels of the international transmission of structural shocks working through relative demand and wealth. Specifically, while we find that a lasting increase in the productivity of tradables is accompanied by a current account deficit - as predicted by the intertemporal-trade approach — the simultaneous appreciation of the price of domestic consumption (the real exchange rate) and exports (proxying for the terms of trade) points to significant effects on relative wealth and de- 
mand. Wealth and price effects in response to supply disturbances consistent with our findings are stressed by recent theoretical contributions to the open economy literature, such as Ghironi and Melitz [2006] and previous work of ours, Corsetti, Dedola, and Leduc [2008]. In the latter contribution, for instance, provided that international financial markets are incomplete and cross-country risk insurance is limited, persistent productivity and output booms in a large, relatively closed country like the United States can induce substantial movements in cross-country wealth and demand that cause both the trade balance to deteriorate and the international price of domestic goods to appreciate. Remarkably, these models show that the international dimension of (persistent) technology shocks is similar to that of demand shocks according to the MFD framework. ${ }^{4}$

This paper relates to a small but significant empirical literature. In notable early work, Clarida and Galí [1994] used long-run restrictions to identify aggregate demand and supply shocks and their effects on the real exchange rate, and cross-country GDP and inflation differentials for the US vis-à-vis the other G7 countries. In previous work (Corsetti, Dedola and Leduc [2006]), we used long-run restrictions to identify technology shocks in the manufacturing sector in a sample of five G7 countries, and found their effects on US relative prices and net trade to be similar to those of productivity shocks above. Here, we propose a novel identification strategy, and focusing on the US experience, we expand considerably the scope of the analysis, by systematically documenting real and financial effects of productivity, as well as demand shocks in the US manufacturing sector. ${ }^{5}$ Finally, this paper differs from contributions such as Canova, Ciccarelli and Ortega [2007], which thoroughly characterizes the empirical features of business cycle comovements among the G7 countries. We instead document in detail the international dimension of identified US shocks, tracing the key channels of the international transmission mechanism.

\footnotetext{
${ }^{4}$ Conversely, our empirical findings are difficult to reconcile with seminal contributions to the modern literature - not only the international real business cycle literature (e.g. see Backus, Kehoe and Kydland [1995] and Stockman and Tesar [1995]), but also the sticky price literature (e.g., see Obstfeld and Rogoff [1995] and Chari, Kehoe and McGrattan [2002]) - which have been developed either under the assumption of complete markets, or using specifications implying a very high degree of international risk sharing. This point is discussed in detail in Section 2.1.

${ }^{5}$ The sign-restriction methodology is also adopted by Enders et al. [2008] for the study of the US real exchange rate dynamics, leading to results for this variable which accounting for differences in identification - are broadly in line with ours.
} 
The paper is organized as follows. Section 2 briefly reviews the international transmission mechanism in standard theoretical and quantitative models, identifying alternative views and empirical predictions on which we base our sign restrictions and define the key questions our empirical analysis will address. Section 3 describes the data and the empirical methodology. Section 4 reports and analyzes in detail our main findings, while Section 5 presents some sensitivity analysis. Section 6 concludes. An appendix describes the data.

\section{Using theory insights to identify produc- tivity and demand shocks}

In this section we motivate and lay out the theoretical underpinnings of our approach to identification. Our identification strategy via sign restrictions consists of focusing on a minimal set of theoretical predictions on the direction of key variables' responses to a given shock, which are consistent with a large class of analytical frameworks. In other words, our identification scheme only hinges on restrictions to variables whose behavior in response to shocks is both unambiguous according to theory and fairly uncontroversial. Conversely, the response of variables for which theory presents a fairly wide range of predictions is left unconstrained - as to reconsider theoretical controversies in light of the results from the analysis.

\subsection{Identification strategy}

Our strategy builds on a straightforward idea: supply-side shifts should move relative prices and quantities in opposite directions, while demand shifts move them in the same direction. Since this idea is especially powerful when applied to sector- or industry-specific shocks, ${ }^{6}$ a natural focus for studies of the international transmission mechanism is on the tradable sector, which we identify with manufacturing. In most open economy models, both productivity and demand shocks in this sector increase relative tradable output; however, productivity gains unambiguously raise the relative price of

\footnotetext{
${ }^{6}$ It is more problematic to identify demand and supply shifts by looking at movements in the level of prices and aggregate quantities - especially because this requires conditioning on a given monetary policy response to shocks.
} 
nontradables - a well-known prediction of the standard Harrod-BalassaSamuelson theory; demand shocks unambiguously reduce it. Thus, we can use the domestic relative price of nontradable in terms of tradables as the key relative price variable in the identification scheme. As explained in Section 2.2, this choice is superior to the alternative of using an international relative price, like the terms of trade. This is because theory's predictions on the response of the international prices to shocks are conditional on strong assumptions about the amount of cross-country insurance, the functioning of international financial markets and more generally on the international transmission mechanism - whose investigation is instead the main objective of our study.

Moreover, focusing on manufacturing not only facilitates identification, but also avoids potentially difficult issues in the interpretation of the results, relative to the alternative of analyzing economy-wide shocks with unspecified industry origin. In this alternative, the response of many macro (internal and external) variables, including relative prices, would indeed be sensitive, among other things, to the distribution of shocks across the tradable and the nontradable sector. In other words, interpreting empirical results would require additional and possibly controversial assumptions about the relative importance of aggregate disturbances in each sector. ${ }^{7}$

By the same token, consistent with our interest in tracing the external effects of shocks to isolate the channels of international transmission, our analysis should naturally focus on those shocks hitting the US asymmetrically vis-à-vis the rest of the world. Failure to impose this requirement would raise issues in interpretation of shocks of unspecified geographic origin, similar to the one discussed above. ${ }^{8}$

Our identification scheme is detailed below.

\footnotetext{
${ }^{7}$ For instance, suppose that we find a positive association between the level of the US economy-wide labor productivity and a terms of trade deterioration. It would be quite difficult to infer that the depreciation is evidence in favor of a particular transmission mechanism without knowing whether the productivity increase is concentrated in tradables or nontradables, and the extent to which the distribution of shocks is stable over time.

${ }^{8}$ The interpretation of the international repercussions of global shocks would again require auxiliary assumptions on their distribution and consequences across countries. For instance, suppose that we find a positive association between the level of US labor productivity and the US trade deficit. Could we infer that this is evidence in support of the intertemporal approach to the current account? Unfortunately, the answer to this question is 'No'. Without controlling for movements in foreign productivity we could not reach this conclusion, as e.g. forcefully argued by Glick and Rogoff [1995].
} 
Productivity in US manufacturing The first shock under consideration consists of supply shocks increasing labor productivity in the US manufacturing sector, relative to that in the rest of the world. To identify these shocks we postulate a set of four restrictions. Positive supply shocks should: (1) Raise (the log of) manufacturing output relative to aggregate output in the US; (2) Lower the relative price of manufacturing - in accordance with the Harrod-Balassa-Samuelson (HBS) effect; (3) Raise US manufacturing output relative to Foreign manufacturing output; and (4) Raise US labor productivity relative to Foreign labor productivity in manufacturing.

As explained above, the theoretical underpinning of restrictions (1) and (2) is that supply shifts move price and quantity in opposite direction: according to standard Harrod-Balassa-Samuelson theory, productivity gains in tradables should increase the domestic price of nontradables in terms of tradables. Restriction (3) isolates shocks with US-specific effects. The last restriction ensures that our identified supply shocks are associated with an increase in relative labor productivity, as it would be the case with standard technology shocks analyzed by the international real business cycle (IRBC) literature. All other variables included in our analysis, namely, aggregate consumption and investment, trade variables, capital flows, international relative prices and asset prices, are left unconstrained, so that the external consequences of productivity shocks can be traced in the data.

Demand for US manufacturing The second shock under consideration consists of demand shifts in favor of US manufacturing goods, relative to all other goods and services produced in the US. The identification of these shocks is based on a set of three restrictions. Positive demand shocks specific to US manufacturing goods should: (1) Raise manufacturing output relative to aggregate output in the US; (2) Raise the relative price of manufacturing in terms of other goods in the economy; and (3) Raise US manufacturing output relative to Foreign manufacturing output.

Restrictions (1) and (2) now capture the theoretical prior that demand shifts move price and quantity in the same direction (rather than in opposite directions, as is the case for productivity shocks); restriction (3) instead isolates shocks that are specific to US tradable production, relative to the other countries in our sample. All other variables included in our analysis are, again, left unconstrained, as to trace the external consequences of demand shocks in the data. 
Caveats and qualifications The two sets of restrictions defined above can be derived from a vast majority of models in the literature. One example which, building on Corsetti and Pesenti [2001], can be solved in closed-form is provided by the stochastic model by Obstfeld and Rogoff [2000]. Other examples are provided by standard IRBC models like that in Stockman and Tesar [1995], or in related work of ours (Corsetti, Dedola and Leduc, [2008]).

We are well aware of the fact that no identification scheme is ironclad. For instance, our productivity shocks clearly capture exogenous shifts in the production function due to technology improvements. Yet, to the extent that measured labor productivity is endogenous, e.g. because of labor hoarding, these shocks could also correspond to other supply disturbances which do not immediately shift the production function, like embodied capital shocks or labor supply shocks.

A potential risk in our analysis is due to the fact that different supply shocks with similar effects on restricted variables may elicit opposite responses of unconstrained variables. In this case, it could be possible that our identified shocks end up having no significant estimated effects on unconstrained external variables. Lack of detectable effects would clearly raise serious interpretation issues.

However, to the extent that our analysis does recover some responses with a high degree of probability, our results provide model builders with quite useful evidence. For a candidate shock to be the main driver of our results, it should be able to account for both the estimated responses of constrained variables, e.g. an increase in labor productivity, as well as the response of any other unconstrained variables we find in the data.

\subsection{International prices and risk sharing in the inter- national transmission mechanism}

As discussed in the introduction, the idea that US expansions cause real dollar appreciation and deteriorate the external balance is widespread in market and policy circle, and well in line with traditional Keynesian models stressing real demand disturbances and competitiveness effects. According to the Mundell-Fleming-Dornbusch framework, these effects are due to real demand booms that in part fall on imported goods and appreciate the currency in nominal and real terms; the appreciation in turn makes domestic goods more expensive, crowding out exports. 
Seminal contributions to the modern literature placing emphasis on supply disturbances - e.g. Backus, Kehoe and Kydland [1995] and Stockman and Tesar [1995] for the international real business cycle IRBC literature, and Obstfeld and Rogoff [1995] and Chari, Kehoe and McGrattan [2002] for the sticky price literature - also predicts that the rise in domestic demand (absorption) during output booms may cause net exports to deteriorate essentially due to the dynamic interplay between saving and investment. However, these contributions envision a different behavior of relative prices: in a boom, the price of exports in terms of imports - i.e. the country's terms of trade - should worsen, and the exchange rate should depreciate in real terms. The key reason for this prediction is that these models have been developed either under the assumption of complete markets, or using specifications implying a high degree of international risk sharing.

To see the link between risk sharing and the response of international prices to shocks, recall that, with full consumption-risk insurance, the ratio of marginal utility of consumption across any two countries is proportional to the relative price of consumption in the two countries, i.e. their bilateral CPI-based real exchange rate (RER) — see e.g. Backus and Smith [1993]:

$$
\frac{U^{\prime}(C)}{U^{\prime}\left(C^{*}\right)}=\kappa \frac{P}{P^{*}}=\kappa \cdot R E R
$$

Here, $C$ denotes domestic consumption, $U^{\prime}($.$) marginal utility, and P$ and $P^{*}$ the domestic and the foreign price levels, expressed in terms of the same numéraire. Under standard assumptions about preferences, the above condition implies that domestic consumption can rise relative to foreign consumption only if its relative price is low, i.e. the real exchange rate simultaneously depreciates.

Since the price levels is a function of the price of nontradables $P N$ and the price of tradable $P T$, for our purpose it is convenient to rewrite the above condition referring to the well-known decomposition of the CPI-based real exchange rate between a first component due to the relative price of tradables across countries, in turn a function of the terms of trade, and a second component due to the relative price of tradables in terms of nontradables 
within countries: ${ }^{9}$

$$
\frac{U^{\prime}(C)}{U^{\prime}\left(C^{*}\right)}=\kappa \cdot R E R\left(\frac{P T}{P T^{*}}, \frac{P N / P T}{P N^{*} / P T^{*}}\right) .
$$

Consider the case of a domestic boom generated by productivity gains in the tradable sector. According to the HBS effect, these gains actually increase the domestic price of nontradables in terms of tradables, $P N / P T$. If the international relative price of domestic tradables $P T / P T^{*}$ did not move, the higher price of nontradables due to the HBS effect would make domestic consumption more expensive relative to foreign consumption, thus appreciating the domestic real exchange rate. But we have seen above that this cannot happen under perfect risk sharing: by the condition (2), domestic consumption can rise with a domestic productivity shocks to tradables only if the real exchange rate simultaneously depreciates. It follows that the international price of domestic tradables must necessarily worsen. ${ }^{10}$

Specifically, the international price of domestically produced tradables i.e. the domestic terms of trade - must fall enough as to outweigh the HBS effect on the relative price of domestic nontradables, up to causing an overall depreciation of the real exchange rate. ${ }^{11}$ We stress here that the same is true in models assuming incomplete markets, yet envisioning allocations that are close to perfect risk sharing, in the sense that they predict a counterfactual positive and high correlation between relative consumption and the real exchange rate - see Cole and Obstfeld [1991], Chari, Kehoe, McGrattan [2002], and our discussion in Corsetti, Dedola and Leduc [2008].

Once the assumptions generating a high degree of risk sharing are relaxed, however, condition (2) no longer determines the equilibrium comovements of relative consumption and the real exchange rate. Without transfers of

${ }^{9}$ In Engel [1999], for instance:

$$
\log R E R \approx \log \frac{P_{T}}{P_{T}^{*}}+\left(1-\gamma^{*}\right) \log \left(\frac{P_{T}^{*}}{P_{N}^{*}}\right)+(1-\gamma) \log \left(\frac{P_{N}}{P_{T}}\right),
$$

where $\gamma$ is the share of traded goods in consumption.

${ }^{10}$ Observe that this must be so independently of the shock persistence, trade elasticity and home bias in domestic demand.

${ }^{11}$ It is easy to verify that a similar argument goes through also in models without nontradables, but home bias in consumption. In this case, the real exchange rate is only a direct function of the terms of trade. Then, a productivity shock raising domestic consumption cannot but depreciate both international prices. 
income via insurance contracts, persistent productivity shocks in the tradable sector can create sizeable wedges in relative wealth and demand. A large response of domestic absorption to productivity gains can strengthen the international price of domestic tradable goods, moving the terms of trade in the same direction as the price of nontradables, and thus complementing, rather than offsetting, the HBS effect. In this respect, it is worth noting that a positive correlation between domestic consumption with terms of trade and real exchange rate appreciation - in violation of the perfect risk-sharing condition (2) - is found by a large body of empirical evidence following the work of Backus and Smith [1993].

Similar considerations apply to shocks to the demand for domestic tradables. Relative to the case of productivity disturbances, a shift in demand for these goods should increase their price both relative to the price of domestic nontradables and relative to the price of foreign tradable goods: other things equal, the first price movement translates into a depreciation of the real exchange rate; the second into a real appreciation. Which of the two effects prevails depends once again on the degree of risk insurance. If markets are complete (as long as the shock raises domestic relative to foreign consumption, without otherwise shifting marginal utilities), the overall outcome cannot be but a real depreciation: the domestic relative price movement cannot be outweighed by the terms of trade movement. If markets are incomplete, either outcome is possible.

These theoretical results thus provide a tight backdrop for our empirical analysis. On the one hand, they support the notion that the domestic relative price of manufacturing goods - our measure of tradables - is a natural candidate for identification via sign restrictions, independently of the degree of international risk sharing. On the other hand, the same discussion qualifies both the real exchange rate and the terms of trade as natural candidates for the list of variables, including net exports, consumption and investment, which should be included as key variables in empirical study of the international transmission of business cycle impulses, and left unconstrained in the analysis.

\section{The empirical framework}

In our analysis, we adopt the VAR methods using sign restrictions similarly to Faust [1998], Uhlig [2005], Canova and De Nicoló [2002] for monetary 
policy shocks, Dedola and Neri [2007] for technology shocks, and Mountford and Uhlig [2005] for fiscal policy shocks. We go over the main elements below, starting with the data sample and the VAR specification, and going into the details of the identification.

Our study analyzes the US vis-à-vis an aggregate of the other G7 countries (Japan, Germany, the UK, and Italy, Canada and France) and three other OECD countries (Australia, Sweden and Ireland) for which we were able to build quarterly data on hourly labor productivity in manufacturing. ${ }^{12}$ As in section 2, we refer to this aggregate as the 'Rest of the World' (ROW). All ROW's variables are built as an aggregate of the above mentioned countries (excluding the US), weighted according to their respective (time-varying) GDP shares at PPP values. ${ }^{13}$

In order to identify shocks which have asymmetric effects across countries, we follow a common approach in the empirical literature: in the tradition of empirical open-economy macroeconomics, we measure all variables (but trade and domestic relative prices) in terms of cross-country differentials (see Clarida and Galí [1994] and Glick and Rogoff [1995]). As is well understood, the alternative of expanding the empirical system to include both US and ROW variables has the clear disadvantage of running quickly against the constraint imposed by data availability, exhausting any degree of freedom in the empirical analysis. A potential issue in working with cross-country differentials is raised by the (implicit) assumption of symmetry across economic areas an assumption which is clearly unappealing in studies focused on small open economies. In our case, however, a symmetry assumption is not obviously consequential, as we compare a large country such as the US, with a large aggregate of OECD countries - we will return on this issue in Section 5. ${ }^{14}$

So, we examine the effects of productivity and demand shocks to the US manufacturing sector, on relative consumption and investment, trade and capital flows, the real exchange rate, the terms of trade and asset prices -

\footnotetext{
${ }^{12}$ These 10 countries add up to roughly half of world GDP at PPP values, so they represent a substantial sample of the global economy. Moreover, trade flows among them also amount to over a half of their respective total trade, on average. For instance, the US trade share with the other 9 countries in our sample is around 60 percent of US total trade.

${ }^{13}$ We use GDP shares as trade weights were not available for all countries going back to 1973.

${ }^{14}$ In our robustness exercises, we will check the symmetry assumption by enlarging our benchmark specification to include country variables in level.
} 
we leave a detailed description of the data sources to the data appendix. The sample period is 1973 - 2004, covering the developments in the international monetary system after the collapse of Bretton Woods (and the longest period for which we have data).

We estimate several specifications of the following reduced form VAR model (omitting the constant):

$$
Y_{t}=B(L) Y_{t-1}+U_{t}
$$

where the vector $Y$ includes the $n$ variables of interest in levels and $B(L)$ is a lag polynomial of order $p$. The covariance matrix of the vector of reducedform residuals $U_{t}$ is denoted by $\Sigma$. In our specifications (unless stated otherwise), the vector $Y_{t}$ is $6 \mathrm{x} 1$. Following a common practice in open-economy VAR studies, we deal with the curse of dimensionality (due to including too many variables with relatively short samples), by keeping the first five variables in $Y_{t}$ fixed, while changing the sixth and last variable across specifications.

The first five variables in $Y_{t}$ are as follows: (i) (the log of) quarterly labor productivity in US manufacturing, in deviation from quarterly labor productivity in manufacturing in the ROW; (ii) the US index of manufacturing production and (iii) aggregate private consumption, both in deviation from the same variable for the ROW; (iv) (the log of) the relative US domestic producer price index over the services consumer price index; and (v) (the log of) real US manufacturing output over US real GDP.

The sixth and last variable in $Y_{t}$ is, in turn, real private investment in the US relative to ROW; the ratio of US nominal net export over US nominal GDP and US real imports and exports of goods; the ratio of US external asset and liabilities and their difference over nominal GDP; and three measures of international relative prices:

$$
R E R(i)_{t}=\frac{P_{t}(i)}{P_{t}^{*}(i)} \quad i=C P I, \text { PPI and Export Deflator. }
$$

The price indexes $P_{t}(i)$ and $P_{t}^{*}(i)$ are alternatively (the log) of the CPI, PPI and export-deflator in dollars. Note that $P^{*}(i)$ is built as a PPP, GDPweighted aggregate of prices for the countries included in ROW. Finally, we also look at the responses of relative equity prices in common currency and short-term interest rate differentials, where the ROW aggregates are computed as above. 
Our empirical implementation closely follows Uhlig [2005]. As is wellknown, the reduced form (3) can be estimated consistently using ordinary least squares (OLS), which, conditional on Gaussian innovations $U_{t}$ and initial conditions, amount to maximum-likelihood (ML) estimation.

In the structural VAR literature, identification amounts to providing enough restrictions as to solve uniquely for the following decomposition of the $n \times n$ estimated covariance matrix of the reduced-form VAR residuals $\Sigma$ (up to an orthonormal transformation $\mathcal{Q}$ such that $\mathcal{Q} \mathcal{Q}^{\prime}=I$ ):

$$
\Sigma=\mathcal{A}_{0} \mathcal{A}_{0}^{\prime}
$$

This matrix equation defines a one-to-one mapping from the vector of orthogonal structural shocks $V$ to the reduced form residuals $U, U=\mathcal{A}_{0} V$. Because of the orthogonality assumption, and the symmetry of $\Sigma$, at least $\frac{n(n-1)}{2}$ restrictions on $\mathcal{A}_{0}$ need to be imposed. ${ }^{15}$

The $\mathrm{j}$-th column of the identification matrix $\mathcal{A}_{0}, \mathcal{A}_{0, j}$, is called an impulse vector in $\mathcal{R}^{n}$, as it maps the innovation to the $\mathrm{j}$-th structural shock $v_{j}$ into the contemporaneous, impact responses of all the $n$ variables, $\Psi_{0, j}$. With the structural impulse vector $\mathcal{A}_{0, j}$ in hand, the set of all structural impulse responses of the $n$ variables up to the horizon $k, \Psi_{1, j}, \ldots, \Psi_{k, j}$ can then be computed using the estimated coefficient matrix $B(L)$ of the reduced form VAR, $B_{1}, B_{2}, \ldots B_{p}$ :

$$
\begin{aligned}
\Psi_{s, j} & =\sum_{h=0}^{s} B_{s-h} \Psi_{h, j}, \quad s \geq 1, B_{s-h}=0, s-h \geq p \\
\Psi_{0, j} & =\mathcal{A}_{0, j} .
\end{aligned}
$$

Proposition 1 in Uhlig [2005] shows that any structural impulse vector $\mathcal{A}_{0, j}$ arising from a given identifying matrix $\mathcal{A}_{0}$ can be represented as $P q$, for an appropriate vector $q$ belonging to the hypersphere of unitary radius $\mathcal{S}^{n} \subset$ $\mathcal{R}^{n}$, and an arbitrary matrix $P$ such that $P P I=\Sigma$. For instance, natural candidates for the orthogonal decomposition $P$ are either the eigenvalueeigenvector or the Cholesky decomposition of $\Sigma$.

Our procedure to obtain estimates of impulse responses consistent with a given set of assumed sign restrictions can be described as follows. Economic theory can be brought to bear, as in Uhlig [2005] or Dedola and Neri [2007], to attribute all the probability mass to the event that the responses of $m \leq n$

\footnotetext{
${ }^{15}$ E.g., see Hamilton [1994], chapter 11.
} 
variables (e.g., relative labor productivity, relative output and so on) to the specific structural shock of interest have a given (positive or negative) sign for $s \leq k$ quarters. For instance, Uhlig [2005] appeals to standard monetary theory and assumes that a contractionary monetary policy shock in the US uniquely brings about a hike in the Federal Fund rate, a drop in the price level and a contraction in money demand (non-borrowed reserves).

Thus, on the basis of theoretical insights, a-priori a non-zero probability is attributed only to structural impulse vectors $A_{0, j}$ which, for a given reducedform estimate of the VAR, yield impulse-responses whose signs are consistent with the assumed restrictions. This could be operationalized to characterize the set of all consistent impulse responses by using the algorithm suggested by Uhlig [2005]: for a given estimate of the VAR reduced-form matrices $\Sigma$ and $B(L)$, and the associated decomposition $P$, we draw (a large number of) candidate $q$ vectors from a uniform distribution over $S^{n}$, and compute the associated impulse vector $A_{0, j}$ and impulse response matrix $\Psi$, discarding those that do not satisfy the assumed sign restrictions. In practice, the $q$ vectors are drawn from a multivariate standard normal and normalized with their Euclidean norm to make sure they have unitary length.

It is important to stress that, while allowing to implement in the identification procedure natural theoretical assumptions (e.g., supply-side shocks should move relative quantities and prices in the opposite direction), sign restrictions lead to a plurality of candidate structural impulse responses. Rather than as a shortcoming, this is a potentially important advantage of this approach, as it allows us to complement our results obtained with exact restrictions, such as long-run restrictions, that could be sensitive to small perturbations to model specification and parameterization. ${ }^{16}$

As argued by Uhlig [2005], the fact that the Bayesian approach views the VAR parameters as random variables, makes it particularly suited to interpreting and implementing sign restrictions. From a Bayesian point of view, on the one hand, the approach amounts to attributing zero probability to reduced-form parameter realizations for which impulse responses contravene the assumed set of sign restrictions. On the other hand, all the impulse responses from the same reduced-form realization that satisfy those restrictions are attributed the same posterior probability. We can thus use

\footnotetext{
${ }^{16}$ For instance, in order to use long-run restrictions in our previous study (Corsetti et al [2006]), we had to proceed under the assumption that productivity shocks be exactly nonstationary and the only source of a stochastic trend in both the level of labor productivity, and its differential across countries.
} 
standard Bayesian methods for estimation and inference, obtaining measures of the uncertainty about estimated impulse responses.

Under a standard diffuse prior on the VAR reduced form parameters $B(L)$ and $\Sigma$, and assuming a Gaussian likelihood for the data sample at hand, the posterior density of the reduced-form VAR parameters with the type of restrictions we implement will be proportional to a standard Normal-Wishart - whose parameters are known functions of the OLS-MLE estimates of the VAR reduced form. Therefore, it is possible to simulate the posterior distribution of impulse responses consistent with our sign restrictions by jointly drawing from the Normal-Wishart posterior for $\Sigma, B(L)$ and the uniform for $q$ over $\mathcal{S}^{n}$, discarding the impulse responses that violate the restrictions. It should be kept in mind that, as stressed by Uhlig [2005], the sign restriction approach amounts to estimating simultaneously the coefficients of the reduced-form VAR and the impulse vector. Draws of the VAR parameters from their unrestricted posterior which do not admit any impulse vector satisfying the imposed sign restrictions are discarded as they have zero prior weight.

\section{The international dimension of productiv- ity and demand shocks to US tradables}

In this section, we present and discuss our empirical findings for productivity and demand shocks identified using the sign restrictions discussed in Section 2 , and conveniently summarized by Table 1, for our estimates with all variables in levels. Results from extensive sensitivity analysis are discussed in the next section.

As shown in Table 1, operationally we require our sign restrictions to be in place for 20 quarters - in the case of the relative price of nontradables (proxied by the PPI over the services CPI) the restriction is in place only from the 5th quarter, as to allow for possible short-run effects of nominal rigidities. The choice of an horizon of 5 years over which the restrictions are imposed reflects the prior that these shocks be mildly persistent - e.g. in the case of an $\mathrm{AR}(1)$ with autoregressive coefficient of 0.75 a $1 \%$ shock will have all but died out after 20 quarters — but is somewhat arbitrary. Therefore, in our robustness exercises, we have also experimented with restrictions over horizons of 28 and 12 quarters. Only the variables listed in the table are 
restricted: the response of all the other variables included in our analysis US net exports over GDP, relative consumption and investment, and of all international relative prices - is left unrestricted.

\section{Table. 1 Sign restrictions on VAR variables}

\begin{tabular}{clcc}
\hline \hline \multicolumn{2}{c}{ Productivity shock } & \multicolumn{2}{c}{ Demand shock } \\
Variable & Horizon in quarters & Variable & Horizon in quarters \\
$L P_{k}-L P_{k}^{*}>0$ & $k=1, \ldots, 20$ & - & - \\
$Y T_{k}-Y T_{k}^{*}>0$ & $k=1, \ldots, 20$ & $Y T_{k}-Y T_{k}^{*}>0$ & $k=1, \ldots, 20$ \\
$Y T_{k}-Y_{k}>0$ & $k=1, \ldots, 20$ & $Y T_{k}-Y_{k}>0$ & $k=1, \ldots, 20$ \\
$P T_{k} / P N_{k}<0$ & $k=5, \ldots, 20$ & $P T_{k} / P N_{k}>0$ & $k=5, \ldots, 20$ \\
\hline \hline
\end{tabular}

In our experiments we typically consider 1000 draws from the posterior, and 5000 rotations each. Table 2 reports the percentage of accepted reduced form draws for which we find at least one vector $q$ satisfying our restrictions. In our experiments, this percentage is usually well above 95 percent, never below 80 percent.

\subsection{Productivity shocks}

The impulse response functions to a positive productivity shock for the specification in Table 1 are displayed in Figures 1,2, 3 and 5. By way of example, Figure 1 displays the response of US relative productivity, manufacturing output (YT-YT*), and aggregate consumption $\left(\mathrm{C}-\mathrm{C}^{*}\right)$, all in log differential with ROW, along with (the log of) manufacturing output over real GDP (YT-Y), the (log of the) PPI relative to the services CPI, and nominal net trade over GDP (NX/Y). Each figure shows the 16th and 84th percentiles (the dashed lines) together with the median (the solid line) of the posterior distribution of the responses satisfying our restrictions in Table 1 for a productivity shock. Charts depicting restricted variables include vertical lines, marking the horizon over which restrictions are imposed. We discuss our main findings analyzing each figure in turn.

Consider first the graphs corresponding to the four restricted variables in Figure 1. The median effect of the productivity shock on relative manufacturing output and labor productivity is of the order of $1 \%$ and $0.5 \%$, respectively. The effect is quite persistent: notably, the 16th percentile of the productivity response is above zero well beyond the 20 quarters over 
which the sign restriction is imposed. The increase of manufacturing output over real GDP is slightly smaller and less persistent. Interestingly, however, the response of (relative) manufacturing output peaks after the first year following the shock. Finally, the productivity shock leads to a prolonged fall in the relative price of domestic tradables already from the second quarter after the shock. This fall corresponds to the HBS effect, that we impose as restriction from the 5 th to the 20th quarter, reflecting the conventional wisdom on the relative price implications of productivity gains in manufacturing. ${ }^{17}$

Focusing now on the two unrestricted variables shown in Figure 1, the responses of relative consumption and net trade are also very substantial and persistent: the 16th percentile of the response of these variables remains positive for the entire period (10 years) displayed in the Figure. Relative consumption rises on impact, and peaks after two years at $0.5 \%$. The fall in net exports is more gradual: the 85th percentile of its response falls below zero after two quarters; the median deficit gradually reaches $-0.1 \%$ of GDP after 4 years. ${ }^{18}$

The prolonged fall in net exports shown in the Figure 1 may be surprising, in light of some applied and policy literature postulating that a productivity increase in tradables should bring about an improvement in net trade. To investigate the source of the trade deterioration, Figure 2 reproduces the responses of relative consumption $\left(\mathrm{C}-\mathrm{C}^{*}\right)$ and net trade, along with relative private investment (I-I*), the CPI-based real exchange rate (RER), and the response of real imports and real exports. Note that all the variables in this figure are unrestricted.

Two findings are worth stressing. First, the deterioration of the trade balance is essentially driven by a rise in real imports: the response of real exports is inconclusive. Therefore, the deterioration in net trade is seemingly

\footnotetext{
${ }^{17}$ It turns out that it is immaterial for our results whether this restriction is imposed from the 5th quarter or from the impact response. The immediate drop in this relative prices makes us confident that our estimates are not contaminated by 'news shocks' of the kind analyzed by Beaudy and Portier [2005] and Jaimovich and Jaimovich and Rebelo [2008], since there is no presumption that anticipated supply-side shifts should move current relative prices and quantities in opposite direction. Interestingly, however, as discussed below, in our identification we find strong wealth and demand effects.

${ }^{18} \mathrm{~A}$ potential concern is that our identification scheme only picks measurement error in manufacturing labor productivity, output and the PPI. If this were the case, however, our overall results would then require this measurement error to be positively correlated with a very persistent increase in relative aggregate consumption (and investment), and a deterioration of net exports - a quite far-fetched set of conditions.
} 
consistent with an increase in US absorption driven by a productivity shock, as predicted by the standard intertemporal-trade approach to the current account. Indeed, relative investment rises persistently mimicking the response of consumption, though it reacts more strongly. Relative investment peaks at around $2 \%$, and reaches back its previous baseline level after 6 years. Second, the CPI-based RER persistently appreciates (an increase is an appreciation) in the aftermath of the shock, then reverts to its baseline, showing some signs of long-run depreciation.

Because of the positive response of relative consumption, the appreciation of the CPI-based RER is at odds with standard conditions for perfect consumption risk sharing - but consistent with the unconditional evidence in Backus and Smith [1993]. This result is of crucial importance in light of the observation, often made in the literature, that a positive correlation between relative consumption and real appreciation in the data could be reconciled with the risk sharing condition (2) to the extent that taste shocks weaken the link between relative marginal utility and consumption. Remarkably, our results document that the full risk sharing condition (2) still fails to hold when measured conditional on productivity shocks only. ${ }^{19}$

The determinants of the striking response of the real exchange rate are further investigated in Figure 3. This figure shows the response of three alternative measures of international relative prices, based on the CPI, the PPI and the export deflator, respectively - the latter denoted as terms of trade (TOT) - together with the response of the export deflator for goods relative to the domestic manufacturing PPI (EXPDEF/PPI). Remarkably, our three measures of international relative prices display the same appreciation pattern. As two of our measures are built using PPIs (i.e. price indexes including a larger share of tradable goods than the CPI) and export deflators (including only the price of traded goods), our results suggest that the CPIbased RER appreciation reflects more than the classical HBS hypothesis (i.e. a rise in the price of nontradables) - in line with the unconditional evidence in Engel [1999]. As shown in the Figure, real appreciation also reflects substantial fluctuations in the relative price of US tradables relative to ROW tradables. Over time, however, US international prices tend to depreciate.

Another intriguing result is that the price of exports in domestic currency

\footnotetext{
${ }^{19}$ Here we greatly expand on our previous analysis in Corsetti et al. [2006], where we only looked at the effects technology shocks on relative consumption, net trade and relative prices.
} 
appears to fall relative to domestic tradables: the 85th percentile of the response of the US export deflator relative to the PPI is negative for almost 30 quarters. This is consistent with the vast body of evidence on deviations from the law of one price and destination-specific markup adjustment (e.g. see the survey by Goldberg and Knetter [1997]). In fact, vis-à-vis the real appreciation of the currency, a fall in the export deflator implies that the US exports price in foreign currency adjusts by less than one-to-one with the exchange rate (see e.g. Atkeson and Burnstein [2008], Corsetti and Dedola [2005] for recent analyses). ${ }^{20}$

To complete our analysis of the response of international prices, Figure 4 shows the probability of RER appreciation and of a TOT improvement, calculated as the frequency that the impulse responses record a strengthening of these relative prices. We find that the probabilities that the real exchange rate appreciates and that the terms of trade improve are 80 percent or higher for roughly 5 years, before gradually declining. ${ }^{21}$

Overall, the evidence displayed in Figures 1 through 4 is consistent with standard international business cycle models with incomplete markets, featuring strong wealth/demand effects of productivity shocks. An instance of model specifications with these characteristics is to be found in related work of ours (Corsetti Dedola Leduc [2008]): when productivity shocks are persistent, and the long-run price elasticity of exports is high enough, the demand for tradables rises above supply in the short run, and appreciates the price of domestic tradable goods relative to Foreign ones. As investment raises the capital stock, output rises over time, reversing the movements in relative prices. $^{22}$

\footnotetext{
${ }^{20} \mathrm{~A}$ different (but possibly complementary) interpretation draws on recent literature in international trade and open economy macroeconomics stressing heterogeneity in productivity among firms (see e.g. Melitz [2003], Ghironi and Melitz [2006], Eaton and Kortum [2002]). A fall in export deflator relative to the PPI would obtain if only the most productive firms export, and/or productivity gains are stronger among exporters. According to this interpretation, the result in the figure would be driven by changes in marginal costs, rather than markup adjustment.

${ }^{21}$ Likewise, we computed the joint probability of a RER appreciation and an increase in $\mathrm{C}^{-} \mathrm{C}^{*}$, quarter by quarter, finding the probability of such an event to be equal to that of a RER appreciation.

${ }^{22}$ In our previous work, we stressed the crucial role of a high trade elasticity as a precondition for this dynamic response. A high elasticity contains the adverse movements in the price of Home tradables when their quantity rises. This means that, other things equal, the present discounted value of future output is higher, so is the increase in wealth. Note
} 
The financial dimension of international transmission is shown in Figure 5. The US stock market increases relative to an aggregate index of foreign markets. Notably, the relative dollar performance of the US stock market — with a differential between 2 and 7 percent — is well beyond the estimated rate of real dollar appreciation - which is below 2 percent. Note that these findings suggest that international diversification in equities would provide US and foreign residents with good opportunities to hedge against the macroeconomic risks implied by our identified productivity shocks.

The short-term interest rate differential is initially zero but becomes positive (in favor of the US) over time, peaking 10 to 15 quarters after the shock. ${ }^{23}$ The positive interest rate differential emerges as the relative domestic demand boom in response to persistent productivity shocks drives the trade into deficit and appreciates the currency in real terms. The estimated response of interest rates is consistent with an endogenously countercyclical stance of monetary policy, leaning against the wind of the perceived demand expansion. ${ }^{24}$

Figure 5 also shows that asymmetric positive productivity disturbances worsen the net foreign asset position of the US - the results in the figure are based on the times series of valuation-adjusted external assets and liabilities calculated by Gourinchas and Rey [2007]. So, the widening of the trade deficit discussed earlier is matched by an overall deterioration of the current account, defined as the difference in net foreign assets between two points in time.

Nonetheless, observe that the fall in the US net foreign wealth corresponds to an increase in the stock of both US gross liabilities and US gross assets (a result also shown, following a different methodology, by Corsetti

however that according to our findings, short-run TOT and RER volatility appears more consistent with relatively low short-run elasticities, raising interesting issues in possible differences in trade elasticities over different horizons.

${ }^{23}$ Comparing this response with that of the real exchange rate, a widening interest differential coexists with a stably appreciated exchange rate, suggesting deviations from uncovered interest parity.

${ }^{24}$ As shown by Chari, Kehoe and McGrattan [2002], even allowing for a high degree of price stickiness, monetary policy cannot by itself generate violations of the risk sharing condition in economies in which the natural rate allocation has consumption growth systematically associated with real depreciation. In other words, no appreciation is possible — with or without nominal rigidities — in the absence of strong wealth effects mirroring fundamental lack of risk sharing. These effects simultaneosly drive both the private sector demand boom, and the policy response to it. 
and Konstantinou [2008]). The rise in the stock of (gross) foreign assets is somewhat surprising. Since the bulk of the US foreign assets are denominated in foreign currency, other things equal, the dollar appreciation documented above tends to reduce the value of their outstanding stock. The observed increase in the value of foreign assets must then be driven by some combination of capital gains in foreign currency, and positive purchases by US residents. This evidence on the conditional comovements of foreign assets and liabilities provides an intriguing empirical benchmark for the recent literature encompassing portfolio diversification in general equilibrium dynamic models after Devereux and Sutherland [2007].

\subsection{Demand shocks}

Figures 6 through 8 display the impulse response functions to a positive demand shock for our benchmark specification, with the same format as Figures 1 to 3 above - each figure reports the 16th and 84th percentiles (the dashed lines) together with the median (the solid line) of the posterior distribution of the responses satisfying our restrictions in Table 1 for a demand shock. As before, vertical lines mark the horizon of restrictions.

Consider Figure 6, presenting the same variables as in Figure 1 - US relative productivity, manufacturing output (YT-YT*), and aggregate consumption $\left(\mathrm{C}^{-} \mathrm{C}^{*}\right)$, all in log differential with ROW, along with (the log of) manufacturing output over real GDP (YT-Y), the (log of the) PPI relative to the services CPI, and nominal net trade over GDP (NX/Y). Comparing Figures 1 and 6 makes it clear that the estimated effects of demand shocks on

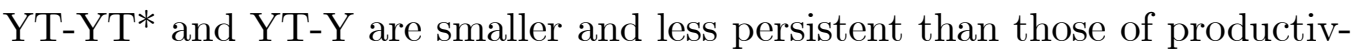
ity shocks; relative labor productivity in manufacturing (now an unrestricted variable) slightly rises on impact - a natural interpretation points to shortrun variations in capacity utilization corresponding to a demand-driven rise in production - but remains unaffected over time. Consumption and net exports do not appear to respond with a large probability.

Aggregate effects of the shock can instead be detected for variables such as investment, and international relative prices. In Figure 7, the 16th percentile of investment is positive between the 15th and the 25th quarter. Yet, the movement in investment is much smaller than its counterpart after a productivity shock. While real imports do not move appreciably, exports in real terms tend to fall moderately over time: the 85th percentile of the respose becomes negative after quarter 20. The CPI-based RER does not respond on 
impact - the median response slightly depreciates. However this variable clearly appreciates after three years, notably around the peak of the investment response. This is so despite the pressure towards real depreciation due to the persistent increase in the price of manufacturing output relative to nontradables displayed in Figure 6.

Figure 8 confirms our previous results, that the response of international relative prices has common determinants going beyond and even countervailing the HBS effect on the US relative price of nontradables: All measures of international prices show the same pattern, appreciating between 3 and 4 years after the shock. Nonetheless, observe that the response of the relative price of export goods relative to overall manufacturing is basically zero, a result which squares well with the presumption that the origin of the shock is mostly domestic. Actually, the slight fall in the median of this relative price is again consistent with imperfect exchange rate pass-through vis-à-vis the currency appreciation (a point already discussed at length in relation to productivity shocks).

Figure 9 shows that demand shocks appear to have little impact on relative US stock prices and interest rates. While net foreign assets - once again using valuation-corrected data - remain utterly unaffected, we detect a small increase in the stocks of both gross assets and liabilities. For the former, the 16th percentile of the response rises above zero between the 5 th and the 15 th quarter.

\section{$5 \quad$ Sensitivity analysis}

In this section, we report on the sensitivity of our results along a number of dimensions. First, we vary the horizon over which sign restrictions are imposed, adding or subtracting 8 quarters relative to the baseline specification in Table 1. Second, we study both shocks simultaneously imposing that they are orthogonal to each other. Third, we address the symmetry assumptions implicit in defining variable as differentials between the US and the rest of the sample. Fourth, we test variants of our sign restrictions and alternative specifications of the model. Finally, observe that as a by-product of the analysis above we experimented with a large set of alternative specifications of the model. For instance, we included different measures of international relative price - using a PPI- instead of a CPI-based real exchange rate. None of the alternative specifications we experimented with displays any significant 
impact on our benchmark results reported above.

Varying the restriction horizon All our results are broadly unchanged when we re-estimate the VAR model imposing our set of restrictions over an horizon which is shorter than in our baseline specification. In the case of productivity shocks, for instance, the main detectable effects of shortening the (upper) restriction horizon from 20 to 12 quarters (while exactly replicating the analysis in all other dimensions) is that the response of all variables to the productivity shock becomes less persistent.

By the same token, imposing that our restrictions bind for up to 28 quarters, i.e. 8 quarters more than our baseline case, increases the persistence of the estimated effects of productivity and demand shocks, as expected. However, lengthening the restriction horizon makes it more difficult to find productivity shocks in the data - we end up rejecting a somewhat larger fraction of draws from the reduced form posterior of our VAR. Similar considerations apply to the case of demand shocks. To save space, we do not report figures for these exercises.

Orthogonal productivity and demand shocks In our analysis, we require the two shocks to have opposite effects on the US relative price of tradables vis-à-vis CPI services, while always increasing US manufacturing output relative to real GDP. In this respect, our identification strategy limits the risk that our results confound their effects. Yet, as we identify productivity and demand shocks individually, without requiring that both be present in the data and be orthogonal to each other, our estimated effects of either shock could potentially be biased - for instance, if the two shocks happen to be negatively correlated with each other. Specifically, in the case of the demand shock, it may happen that some of the estimated responses, while picking up the assumed positive demand shock, could be contaminated by a (weaker) negative productivity shock. For instance, this could have the effect of strengthening the positive response of the relative price of tradables, while attenuating that of other variables, like relative output or consumption.

The change in the procedure described in Section 3 needed to produce two sets of candidate impulse responses which are orthogonal on impact is straightforward. We now need to find two vectors, $q_{1}$ and $q_{2}$, both belonging to the hypersphere of unitary radius $\mathcal{S}^{n} \subset \mathcal{R}^{n}$, which also satisfy the additional orthogonality condition $q_{1}^{\prime} q_{2}=0$; then, we can compute the two 
impulse vectors $P q_{1}$ and $P q_{2}$ and the related impulse responses, verifying that they satisfy the sign restrictions for productivity and demand shocks. In practice, the vectors are again drawn from a multivariate standard normal, then orthogonalized and normalized with their Euclidean norm to make sure they have unitary length.

Orthogonality may have a further important consequence for our results. Since the number of restrictions imposed simultaneously is larger, it may be more difficult to find the two shocks in the data, leading us to reject a much higher number of reduced forms in our estimation procedure. This could affect our findings, that each shock individually is very likely to be present in the data. Yet, when we estimate orthogonal productivity and demand shocks imposing the restrictions in the two columns of Table 1 simultaneously, we find virtually no difference from the results for each shock in isolation. Once again, to save space, we do not report figures for these exercises.

Cross-country symmetry An important robustness check consists in testing whether the symmetry assumption implicit in estimating VARs in crosscountry differentials be a source of bias in our results. To address this specification issue we first investigated potential sources of bias by regressing the residuals from our baseline six-variable specification of the VAR model on the levels of all our variables, for both the US and the rest of the world. Second, we re-estimate our model using a larger VAR, in which we include the variable(s) which turn out to be significant in the auxiliary regressions estimated in the first step.

Interestingly, the only such variable in the auxiliary regressions is productivity in manufacturing in the US - suggesting that its specification in the benchmark VAR in differential with the rest of the world could be a potential source of bias. Thus we re-estimate a seven-variable VAR, including this variable, left unconstrained, in order to keep our identification unaltered. The results from this exercise are broadly similar to those from our benchmark. This is clearly shown by Figure 10, which displays a selection of our variables, using the same format as before - each chart display the 16th and 84th percentiles (the dashed lines) together with the median (the solid line) of the posterior distribution of the responses satisfying the restrictions. Notably, the level of US labor productivity in manufacturing, which is left unconstrained, rises persistently with a high probability, closely mirroring the response of the (constrained) productivity differential; all the other 
variables, both restricted (YT-YT*, YT-Y and PPI/CPI) and unrestricted, behave in a similar way as before under the symmetric specification. Overall, this is evidence that the symmetry assumption does not appear to drive our findings in a significant way.

Changing sign restrictions As seen above, the response of many macro variables to demand shocks identified according to our benchmark scheme tends to be subdued. As a robustness exercise, we check the implications of imposing the additional restriction that relative consumption increases in response to demand disturbances for 8 quarters. The goal of this experiment is to verify whether a more restricted specification, isolating sharply the effects of demand shocks with a prevailing domestic origin in one important component of absorption, would result into more conclusive results for a larger set of variables.

We find that demand shocks associated with an increase in relative consumption tend to have stronger effects on trade variables, as the response of gross and net exports now becomes clearly negative. However, these shocks now have weaker effects on investment and international relative prices, as shown in Figure 11 and 12, reproducing the responses of the same variables as in Figure 6 and 7, respectively.

Specifically, consider Figure 11, including the same variables as in Figure 6 - US relative productivity, manufacturing output (YT-YT*), and aggregate consumption $\left(\mathrm{C}^{-} \mathrm{C}^{*}\right.$ ), all in log differential with ROW, along with (the log of) manufacturing output over real GDP (YT-Y), the (log of the) PPI relative to the services CPI, and nominal net trade over GDP (NX/Y). The estimated effects of demand shocks on relative consumption (restricted in Figure 11 to increase for the first 2 years) and net exports are now much more clear cut, with the latter turning negative for some periods. Figure 12 shows that the trade deficit mainly reflects a persistent drop in real exports, while the response of real imports appear inconclusive. Relative to Figure 7, however, the response of investment and the CPI-based RER is now much smaller and also inconclusive.

This robustness experiment shows that augmenting with further restrictions our benchmark scheme for demand shocks leads to the identification of a demand disturbance with quite different effects from those estimated under the benchmark. This supports the notion that our benchmark restrictions are isolating the effects of a specific demand shock to US manufacturing, 
whose aggregate effects materialize mainly on international relative prices and on domestic components of investment, but not in consumption and net trade.

\section{Conclusions}

In this paper, we provide novel empirical evidence on the international dimension of productivity and demand shocks in the US, vis-à-vis an aggregate of other large industrial countries. Identification is based on sign restrictions derived from clear-cut and robust predictions by standard theory, regarding the effects of shocks concentrated in the tradable sector. Relative to the existing literature, our contribution is novel in that it applies to international data VAR methods with minimal identifying assumptions, but strong theoretical underpinnings, to document both the real and financial channels of the international transmission in detail. For all our results, we conduct extensive robustness analysis, changing the specification of the model, varying the restrictions' horizon, including additional variables, imposing orthogonality between shocks, or changing variables' definitions.

Our study provides evidence on the cross-country transmission of US structural demand and supply shocks in remarkable agreement with what we have called the popular market and policy view. First, we find that sectoral demand shocks in US tradables, while having limited aggregate effects on absorption and net trade, still affect specific demand components, especially investment, and appreciate the real value of the dollar. Second and more strikingly, we find that sectoral productivity shocks in US tradables have a non-trivial impact on aggregate demand, suggesting that an important dimension of their transmission operates via intertemporal general equilibrium effects on cross-country wealth. Namely, our identified productivity shocks boost US consumption and investment, relative to the rest of the world, thus raising real imports. The overall deterioration of the US trade balance is then matched by a fall in the (valuation adjusted) stock of US net foreign assets. The value of the US stock market persistently rises above the market value abroad. Over time, the domestic short-term interest rate rises above the foreign one. We also find that all our measures of international relative prices - CPI-based, PPI-based and export-deflator based exchange rates

- appreciate in response to these shocks, although they tend to depreciate below their initial levels in the long run. 
The implied wealth and aggregate demand effects of productivity shocks are at odds with a key transmission channel typically postulated by textbook open-economy models - that a higher supply of tradables must be matched by a fall in a country's terms of trade - , and have important implications for cross-country risk sharing. As pointed out by Cole and Obstfeld [1991], a fall in international relative prices of domestic tradables partly offsetting productivity and output differentials would provide consumption risk insurance by containing differences in national demand and wealth: international price movements would then substitute for asset income payments from internationally diversified portfolios. In contrast, our estimates suggest that movements in the international prices of US traded goods and consumption are far from providing risk insurance against US productivity fluctuations while movements in relative prices of assets such as stocks apparently do.

Our results complement the findings in Backus and Smith [1993] that domestic consumption on average rises when the currency appreciates, by showing that this feature of the data also emerges conditional on identified productivity shocks only. Not only is this clear evidence of lack of consumption risk sharing vis-à-vis productivity disturbances, together with the rest of our analysis, it emphasizes imperfect risk sharing as an essential element in the characterization of the transmission mechanism, and suggests that strong wealth effects play an important role in generating aggregate demand fluctuations across countries.

In this sense, our findings provide an empirical benchmark for the development of open economy models, and a base for further theoretical and empirical investigation. There is a clear need for reconsidering mechanisms through which structural shocks can generate sizeable wedges between domestic and foreign demand - a task which has been recently pursued by developing open economy models under the assumption of incomplete markets, emphasizing the role of relative wealth effects and/or market dynamics, but that could also motivate new directions for research on global macroeconomic interdependence. 


\section{Appendix 1 Data description and sources}

\section{United States}

Labor productivity: Index of output per hour of all persons in manufacturing sector, seasonally adjusted, $1992=100$ (Bank of International Settlements and Dept. of Labor).

Manufacturing output: Index of industrial production in manufacturing, seasonally adjusted, $2000=100$ (Federal Reserve Board)

Consumption: Private final consumption expenditure, volume in national currency, seasonally adjusted (OECD, Economic Outlook Database).

Nominal GDP: Gross domestic product, value, market prices in national currency, seasonally adjusted (OECD, Economic Outlook Database)

Net exports:Nominal net exports of goods \& services, value in national currency, seasonally adjusted (OECD, Economic Outlook Database)

Real imports and exports:Real imports and exports of goods, national currency, seasonally adjusted, $2000=100($ NIPA, Table 4.2.3)

PPI index: Producer price index of manufactured products, seasonally adjusted, $2000=100$ (OECD, Main Economic Indicators Database)

CPI total: Consumer price index all items, seasonally adjusted, $2000=100$ (OECD, Main Economic Indicators Database)

CPI services: Consumer price index for services less energy services, seasonally adjusted; 1982-84 = 100, monthly converted to quarterly averages (BLS) Export deflator: Exports of goods, deflator, seasonally adjusted, national accounts basis; $2000=100$ (OECD, Economic Outlook Database)

Short-term rate: Federal Fund Rate, quarterly (IMF, International Financial Statistics)

Stock prices: Share Prices, quarterly (IMF, International Financial Statistics)

US Foreign assets and liabilities:Valuation adjusted US net foreign assets, gross foreign assets and gross foreign liabilities (Gourinchas and Rey [2007], 
Appendix B)

CPI-based real exchange rate: Index of ratio of US CPI (total) to aggregate CPI (total) of 9 OECD countries, all in current US dollars, weighted with GDP shares at annual PPP values, 1970q1 = 100 (authors calculations based on OECD, Economic Outlook Database)

PPI-based real exchange rate: Index of ratio of US PPI (manufacturing) to aggregate PPI (manufacturing) of 9 OECD countries, all in current US dollars, weighted with GDP shares at annual PPP values, 1971q1 = 100 (authors calculations based on OECD, Economic Outlook Database)

Terms of trade: Index of ratio of US export deflator (goods and services) to aggregate export deflator (goods and services) of 9 OECD countries, all in current US dollars, weighted with GDP shares at annual PPP values, 1970q1 $=100$ (authors calculations based on OECD, Economic Outlook Database)

Relative stock prices: Index of ratio of US stock prices to aggregate stock prices of 9 OECD countries, all in current US dollars, weighted with GDP shares at annual PPP values, 1970q1 = 100 (authors calculations based on IMF, International Financial Statistics)

\section{Rest of the world}

The rest of the world comprises Japan, Germany, UK, Italy, France, Canada, Australia, Sweden and Ireland. This choice was dictated by data availability regarding hourly productivity in manufacturing.

Individual country's variables were aggregated by first taking quarterly growth rates to remove national basis effects; then cross-country average growth rates were computed with weights based on each country's GDP share in the 9-country aggregate calculated at annual purchasing power parity (PPP) values. Average growth rates were then cumulated starting from the initial base year to obtain levels.

Annual PPP based GDP shares are from the IMF's World Economic Outlook Database from 1980; before 1980 they were computed directly on the basis of annual GDP at PPP values form OECD's Economic Outlook Database.

Labor productivity: Aggregate of country-specific indexes of output per hour of all persons in manufacturing sector, seasonally adjusted, 1970q1 = 100 (au- 
thors calculations based on national statistical sources, BIS and IMF)

Manufacturing output: Aggregate of country-specific indexes of industrial production, manufacturing, seasonally adjusted, 1970q1 = 100 (authors calculations based on national statistical sources, BIS and IMF)

Consumption and investment: Aggregate of country-specific private final consumption expenditure, volumes in national currency, seasonally adjusted, 1970q1 = 100 (authors calculations based on OECD, Economic Outlook Database).

Stock prices: Aggregate of country-specific share prices, 1970q1 $=100$ (authors calculations based on IMF, International Financial Statistics and BIS (for UK only)).

Short-term rates: Weighted average with PPP GDP weights of countryspecific gross short-term rates (authors calculations based on IMF, International Financial Statistics). 


\section{References}

[1] Andersen, Torben G.; Tim Bollerslev; Francis X. Diebold; and, Clara Vega, [2003]. "Micro Effects of Macro Announcements: Real-Time Price Discovery in Foreign Exchange," American Economic Review 93, pp. 38-62.

[2] Atkeson, Andrew, and Ariel Burstein, [2008]. "Pricing-to-Market in a Ricardian Model of International Trade," American Economic Review, forthcoming.

[3] Backus, David K., Patrick J. Kehoe, and Finn E. Kydland [1995]. "International Business Cycles: Theory and Evidence," in Thomas F. Cooley (ed.) Frontiers of Business Cycle Research, Princeton University Press, Princeton, pp. 331-56.

[4] Backus, David K., and Gregor W. Smith, [1993]. "Consumption and Real Exchange Rates in Dynamic Economies with Non-traded Goods," Journal of International Economics 35, pp. 297-316.

[5] Beaudry, Paul and Franck Portier, [2006]. "Stock Prices, News, and Economic Fluctuations," American Economic Review, 96, pp. 1293-1307.

[6] Canova, Fabio, and Gianni De Nicolo [2002]. "Monetary Disturbances Matter for Business Fluctuations in the G-7," Journal of Monetary Economics 49, pp. 1131-59.

[7] Canova, Fabio, Matteo Ciccarelli and Eva Ortega [2007]. "Similarities and convergence in G-7 cycles," Journal of Monetary Economics 54, pp. 850-878.

[8] Chari, V.V., Patrick J. Kehoe, and Ellen McGrattan [2002]. "Can Sticky Prices Generate Volatile and Persistent Real Exchange Rates?," Review of Economic Studies 69, pp. 633-63.

[9] Clarida, Richard, and Jordi Galí [1994]. "Sources of Real Exchange Rate Fluctuations: How Important Are Nominal Shocks?" CarnegieRochester Series in Public Policy 41, pp. 1-56

[10] Cole, Harold L., and Maurice Obstfeld [1991]. "Commodity Trade and International Risk Sharing: How Much Do Finacial Markets Matter?" Journal of Monetary Economics 28, pp. 3-24. 
[11] Corsetti Giancarlo, Panagiotis Konstantinou [2008]. "Current account adjustment and the dynamics of foreign assets and liabilities in the US" mimeo.

[12] Corsetti Giancarlo, and Luca Dedola [2005]. "A macroeconomic model of international price discrimination," Journal of International Economics 67, pp. 129-155.

[13] Corsetti Giancarlo, Luca Dedola and Sylvain Leduc [2006]. "Productivity, External Balance and Exchange Rates: Evidence on the Transmission Mechanism Among G7 Countries," NBER International Studies on Macroeconomics.

[14] Corsetti Giancarlo, Luca Dedola and Sylvain Leduc [2008]. "International Risk-Sharing and the Transmission of Productivity Shocks," Review of Economic Studies 75, pp. 443-473.

[15] Corsetti Giancarlo and Gernot Mueller [2006]. "Twin Deficits: squaring theory evidence and common sense," Economic Policy 48, pp. 597-638.

[16] Corsetti, Giancarlo, and Paolo Pesenti [2001]. "Welfare and Macroeconomic Interdependence," Quarterly Journal of Economics 116, pp. 421446.

[17] Dedola, Luca and Stefano Neri [2007]. "What does a technology shock do: A VAR analysis with model-based sign restrictions," Journal of Monetary Economics 54, pp. 512-549.

[18] Devereux, Michael B. and Alan Sutherland [2007]. "Country Portfolios in Open Economy Macro Models," manuscript.

[19] Dornbusch Rudiger [1980], "Exchange Rate Economics: Where Do We Stand", Brookings Papers on Economic Activity 1, pp. 143-185.

[20] Eaton, Jonathan and Samuel Kortum [2002]. "Technology, Geography and Trade," Econometrica 70, pp. 1741-79.

[21] Eichenbaum, Martin and Charles L. Evans. "Some Empirical Evidence on the Effects of Shocks to Monetary Policy on Exchange Rates," Quarterly Journal of Economics 110, pp. 975-1009. 
[22] Enders Zeno, Gernot J. Müller and Almut Scholl [2008], "How do Fiscal and Technology Shocks affect Real Exchange Rates? New Evidence for the United States", Center for Financial Studies, Working Paper $2008 / 22$.

[23] Engel, Charles [1999]. "Accounting for Real Exchange Rate Changes," Journal of Political Economy 107, pp. 507-38.

[24] Engel, Charles, Nelson Mark and Ken West [2007]. "Exchange Rate Models Are Not as Bad as You Think," NBER Macroeconomics Annual.

[25] Faust, Jon [1998]. "The Robustness of Identified VAR Conclusions about Money," Carnegie-Rochester Conference Series on Public Policy 49, pp. 207-44.

[26] Goldberg, Pinelopi and Michael M. Knetter, [1997]. "Goods Prices and Exchange Rates: What Have We learned?," Journal of Economic Literature 35, pp. 1243-1272.

[27] Ghironi, Fabio and Marc Melitz [2006]. "International Trade and Macroeconomics Dynamics with Heterogenous Firms," Quarterly Journal of Economics, pp. 865-915.

[28] Gourinchas, Pierre Olivier, and Helene Rey [2007]. "International Financial Adjustment," Journal of Political Economy 115, pp. 665-703.

[29] Glick, Reuven, and Kenneth Rogoff [1995]. "Global versus CountrySpecific Productivity Shocks and the Current Account," Journal of Monetary Economics 35, pp. 159-92.

[30] Hamilton, James D. [1994]. Times Series Analysis, Princeton: Princeton University Press.

[31] Jaimovich J. and Sergio Rebelo, "Can News about the Future Drive the Business Cycle?," American Economic Review, forthcoming.

[32] Kim, Soyoung, and Nouriel Roubini [2008], "Twin deficit or twin divergence? Fiscal policy, current account, and real exchange rate in the U.S." Journal of International Economics, 74, pp. 362-383. 
[33] Melitz, Marc [2003]. "The Impact of Trade on Intra-Industry Reallocations and Aggregate Industry Productivity," Econometrica 71, pp. 1695-1725.

[34] Mountford, Andrew, and Harald Uhlig [2005], "What are the effects of fiscal policy shocks? Results from an agnostic identification procedure," CEPR Discussion Papers 3338.

[35] Obstfeld, Maurice [1982]. "Aggregate Spending and the Terms of Trade: Is There a Laursen-Metzler Effect," Quarterly Journal of Economics 97, pp. 251-270.

[36] Obstfeld, Maurice, and Kenneth Rogoff [1995]. "Exchange Rate Dynamics Redux," Journal of Political Economy 103, pp. 624-655.

[37] Obstfeld, Maurice, and Kenneth Rogoff [2000]. "New Directions for Stochastic Open Economy Models." Journal of International Economics 50, February, pp. 117-153.

[38] Stockman, Alan C., and Linda Tesar [1995]. "Tastes and Technology in a Two-Country Model of the Business Cycle: Explaining International Comovements," American Economic Review 83, pp. 473-486.

[39] Svensson Lars and Assaf Razin [1983], "The Terms of Trade and the Current Account: the Harberger-Laursen-Metzler Effect", Journal of Political Economy 91, pp. 97-125.

[40] Uhlig, Harald [2005], "What are the effects of monetary policy on output? Results from an agnostic identification procedure," Journal of Monetary Economics 52, pp. 381-419. 


\section{Table 2}

Acceptance rates of reduced forms draws: Individual shocks

Sample is 1974:1-2004:4

$$
\text { Productivity Demand }
$$

Net exports over GDP

$98.90 \%$

$98.40 \%$

Real exports

$79.90 \%$

$95.90 \%$

Real imports

$96.50 \%$

$95.10 \%$

Relative investment

$99.70 \%$

$98.70 \%$

CPI-based RER

$99.30 \%$

$99.10 \%$

PPI-based RER

$99.20 \%$

$99.20 \%$

Terms of trade

$99.10 \%$

$98.50 \%$

Exp. Deflator/PPI

$90.70 \%$

$95.40 \%$

Share prices

$91.70 \%$

$96.20 \%$

Interest rate differential

$98.80 \%$

$95.40 \%$

Foreign assets over GDP

$96.80 \%$

$98.20 \%$

Foreign liabilities over GDP

$94.80 \%$

$96.80 \%$

Net foreign assets over GDP $99 \%$ $97.70 \%$ 
Figure 1
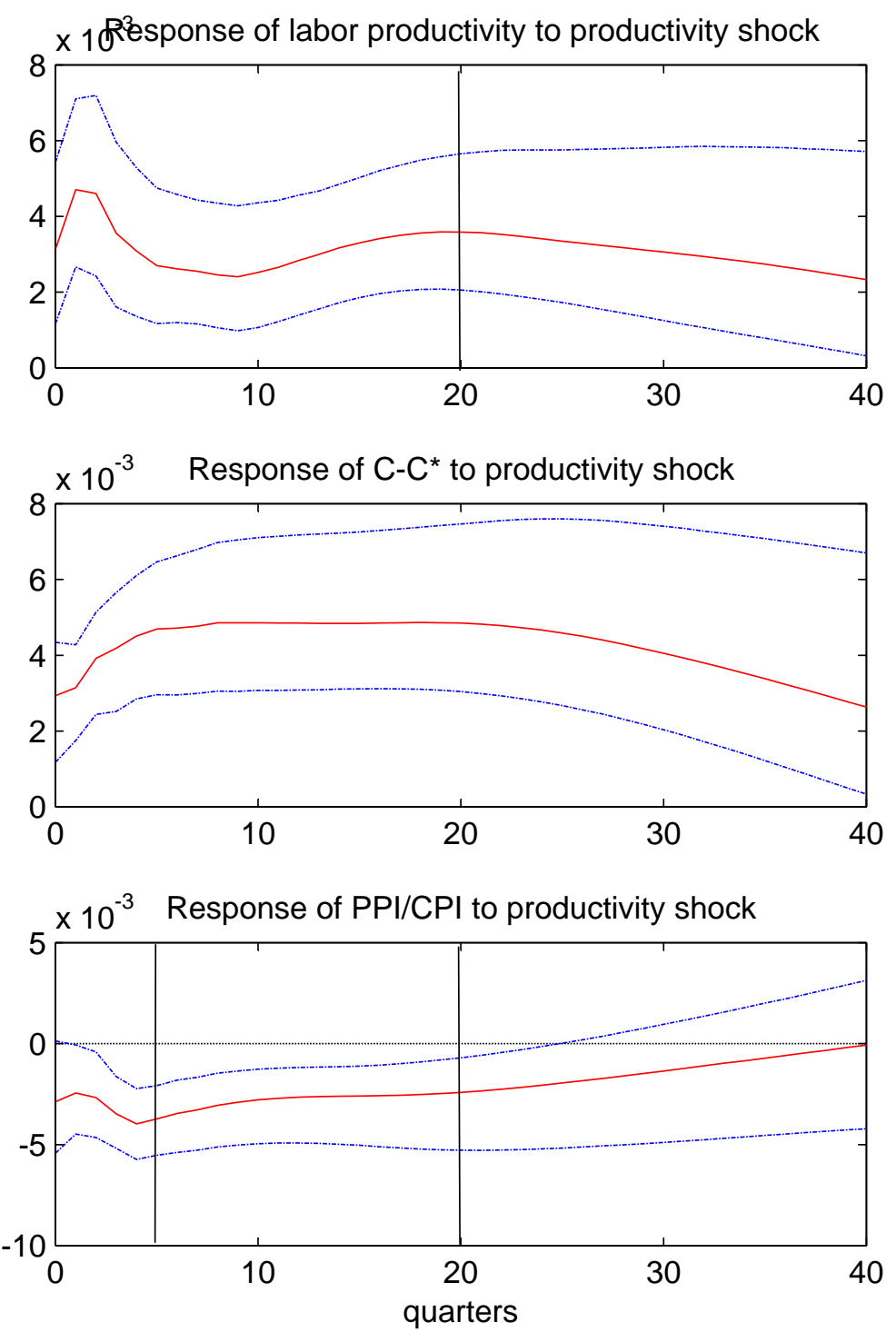
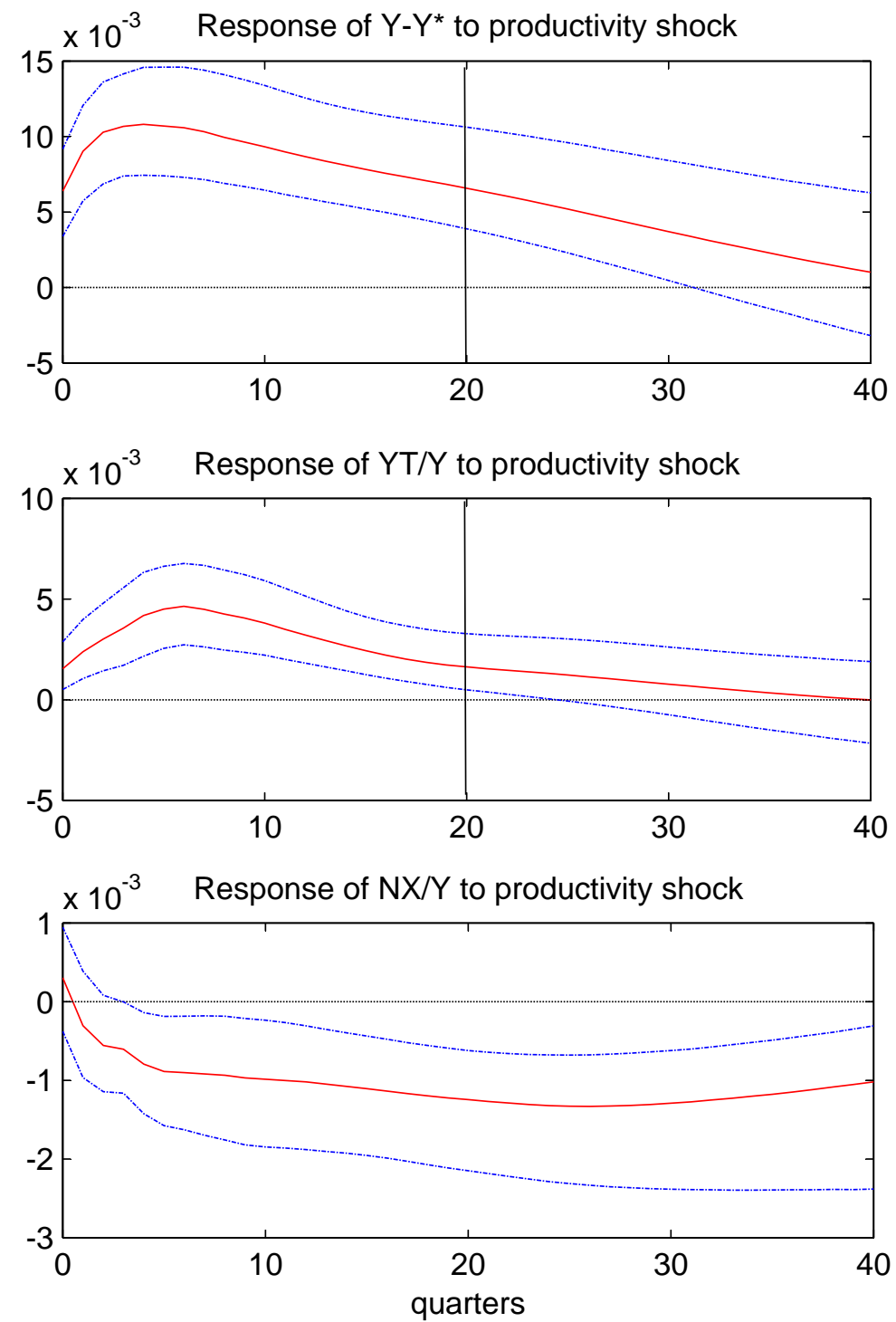
Figure 2
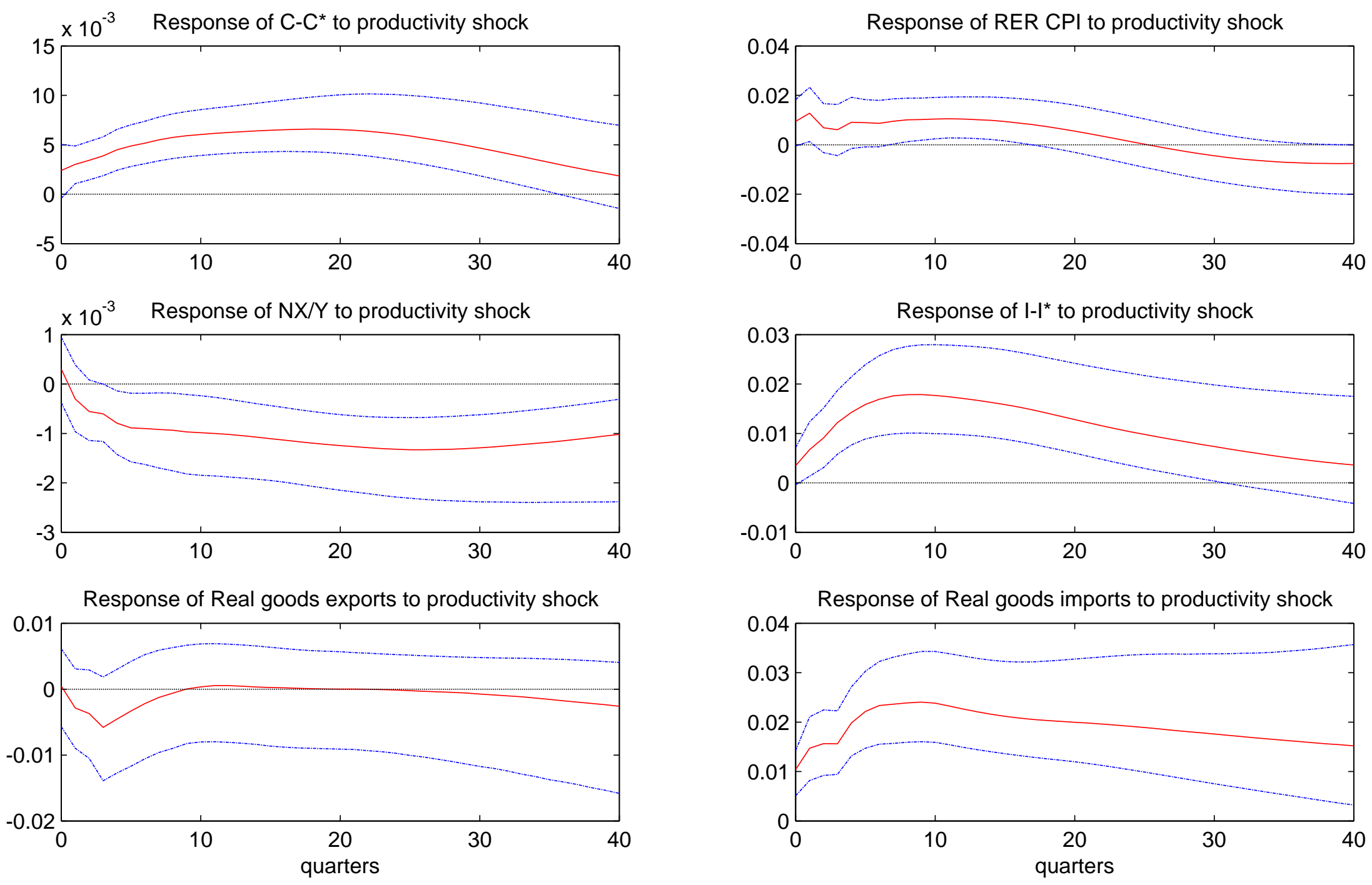
Figure 3

Response of RER CPI to productivity shock

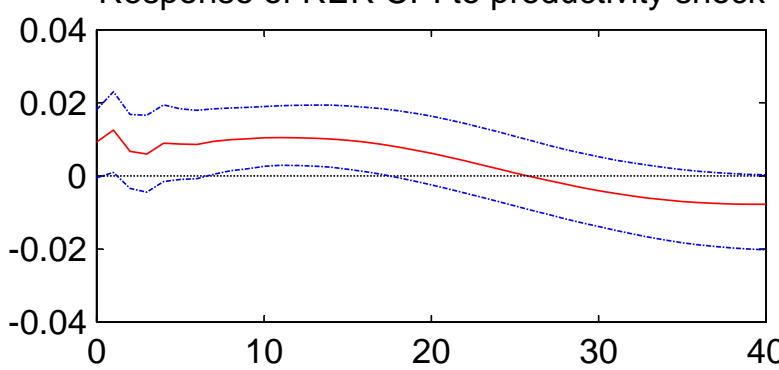

Response of TOT to productivity shock

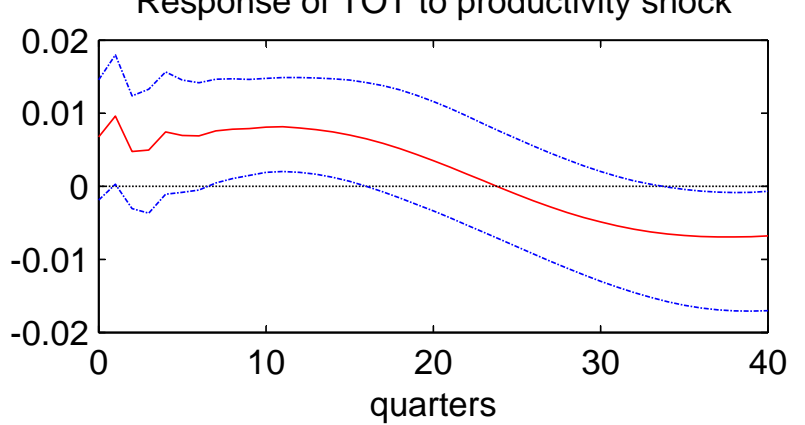

Response of RER PPI to productivity shock

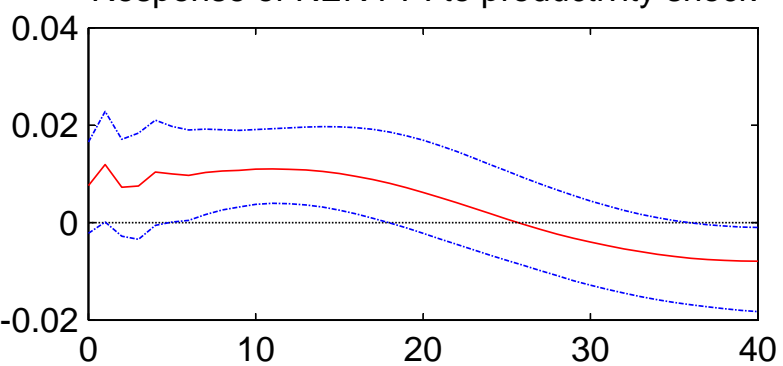

Resporise of EXPDEF/PPI to productivity shock

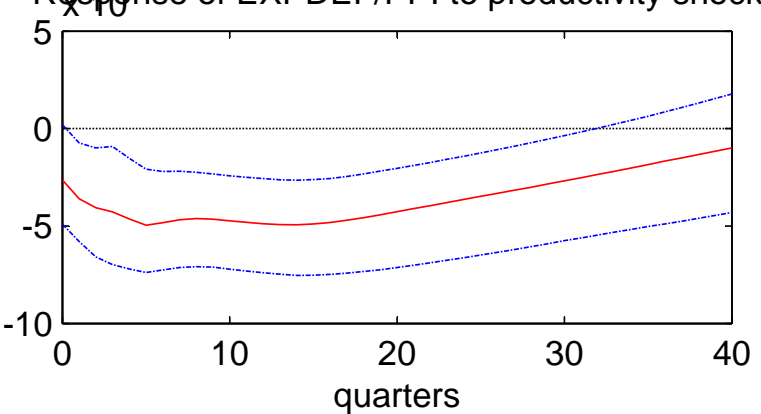

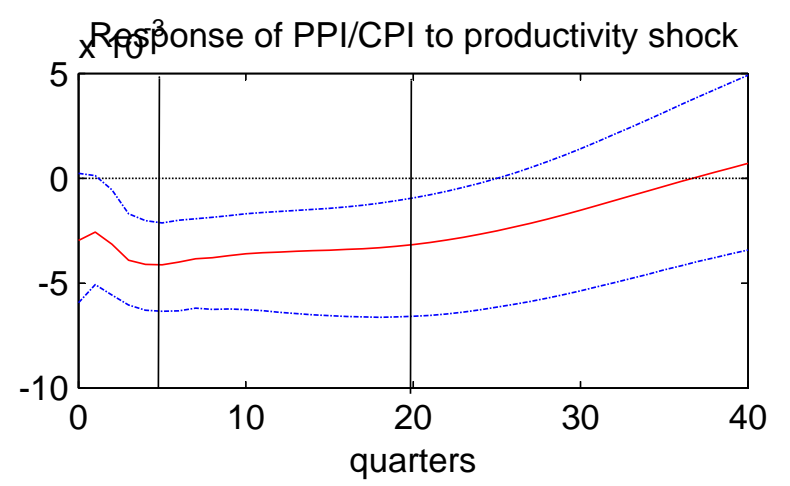


Figure 4

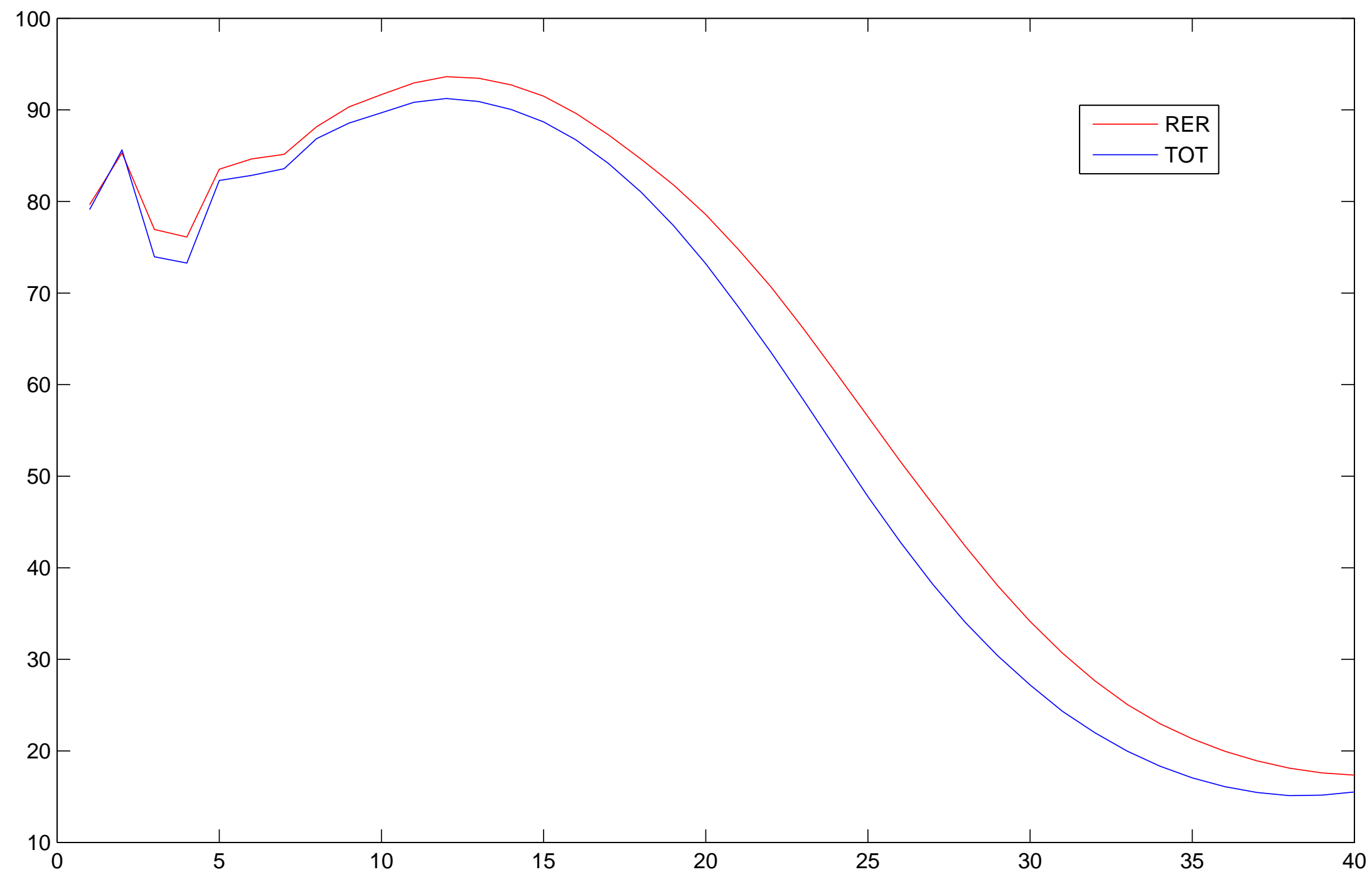


Figure 5
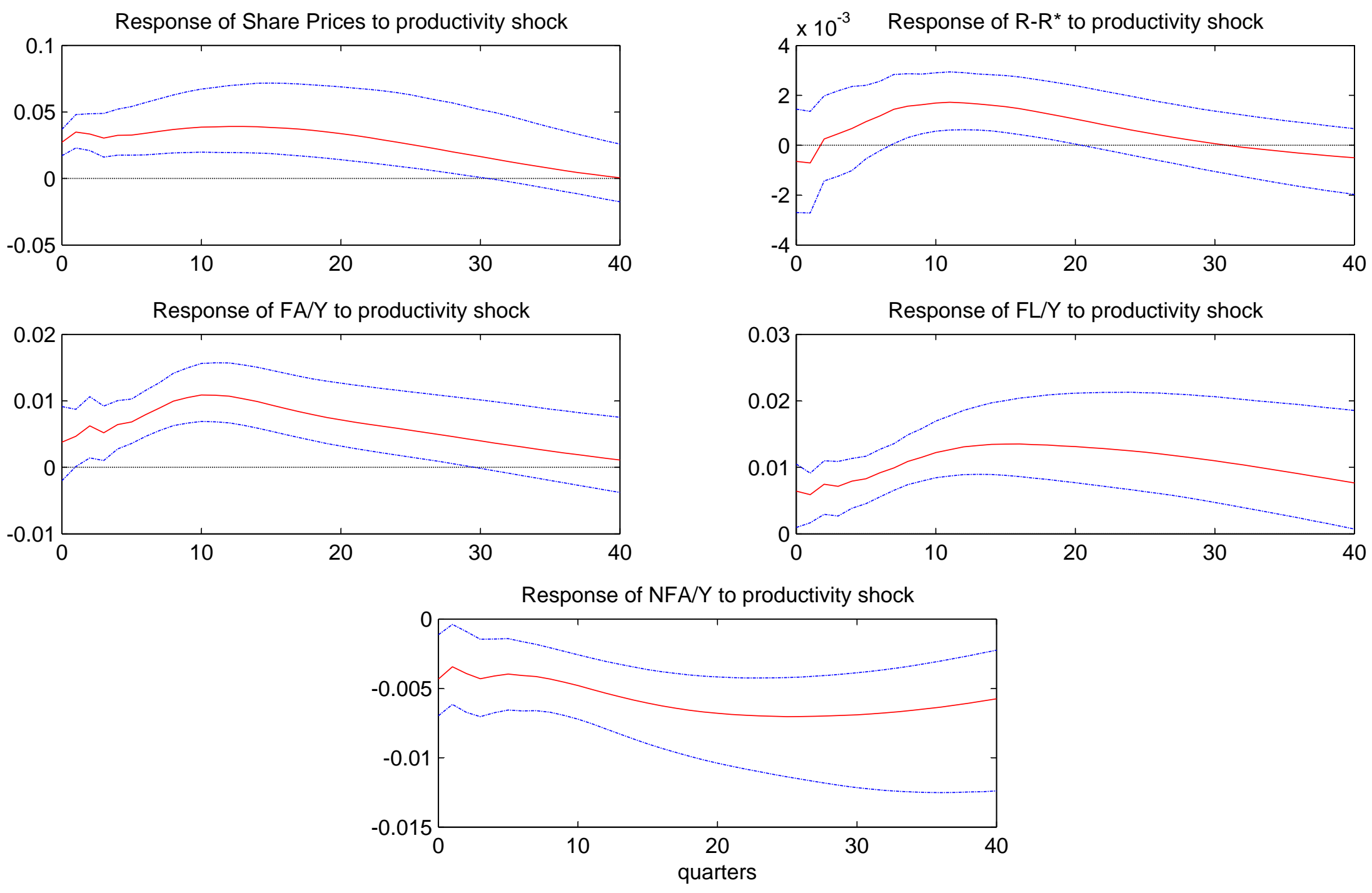
Figure 6
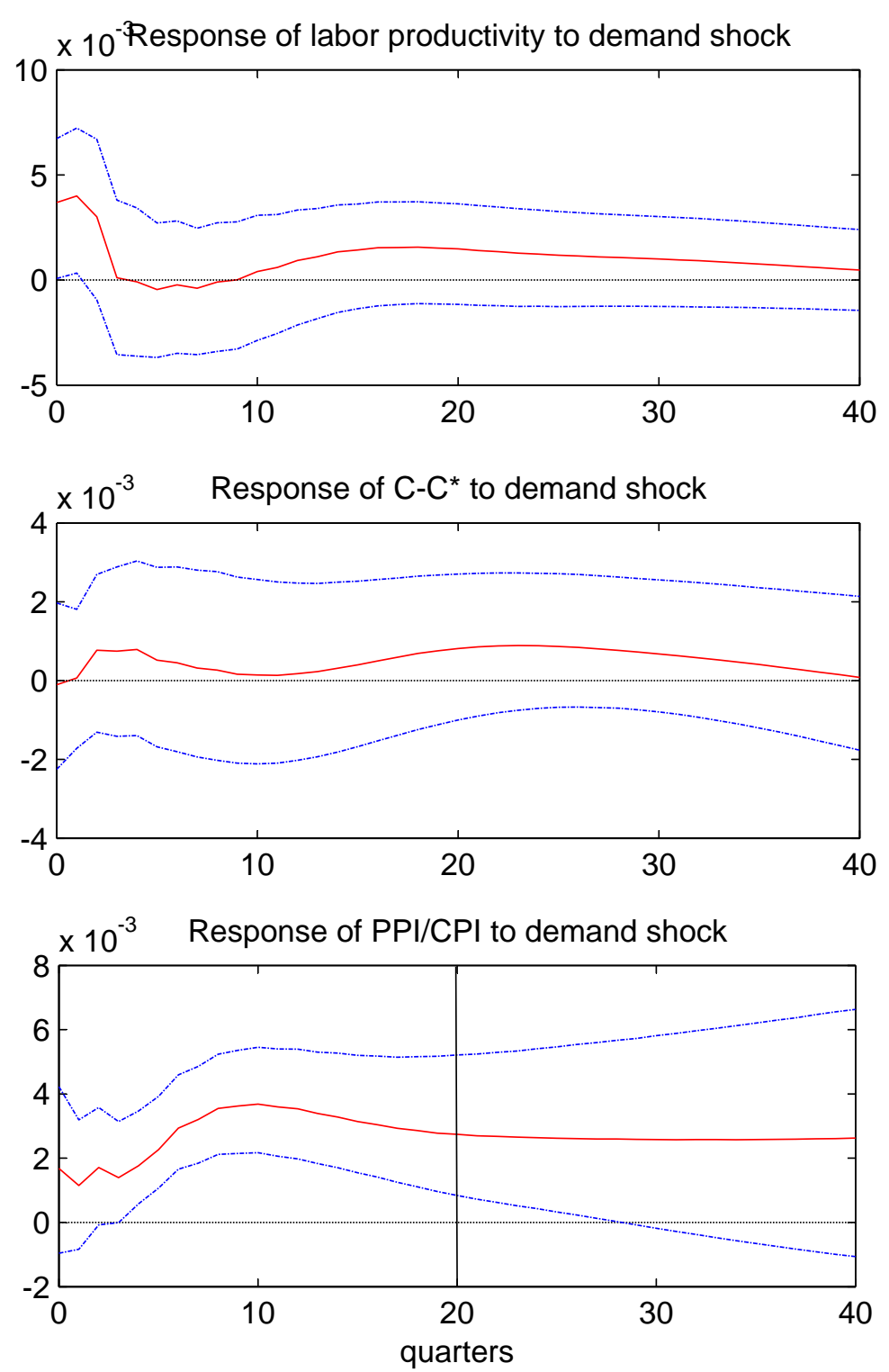
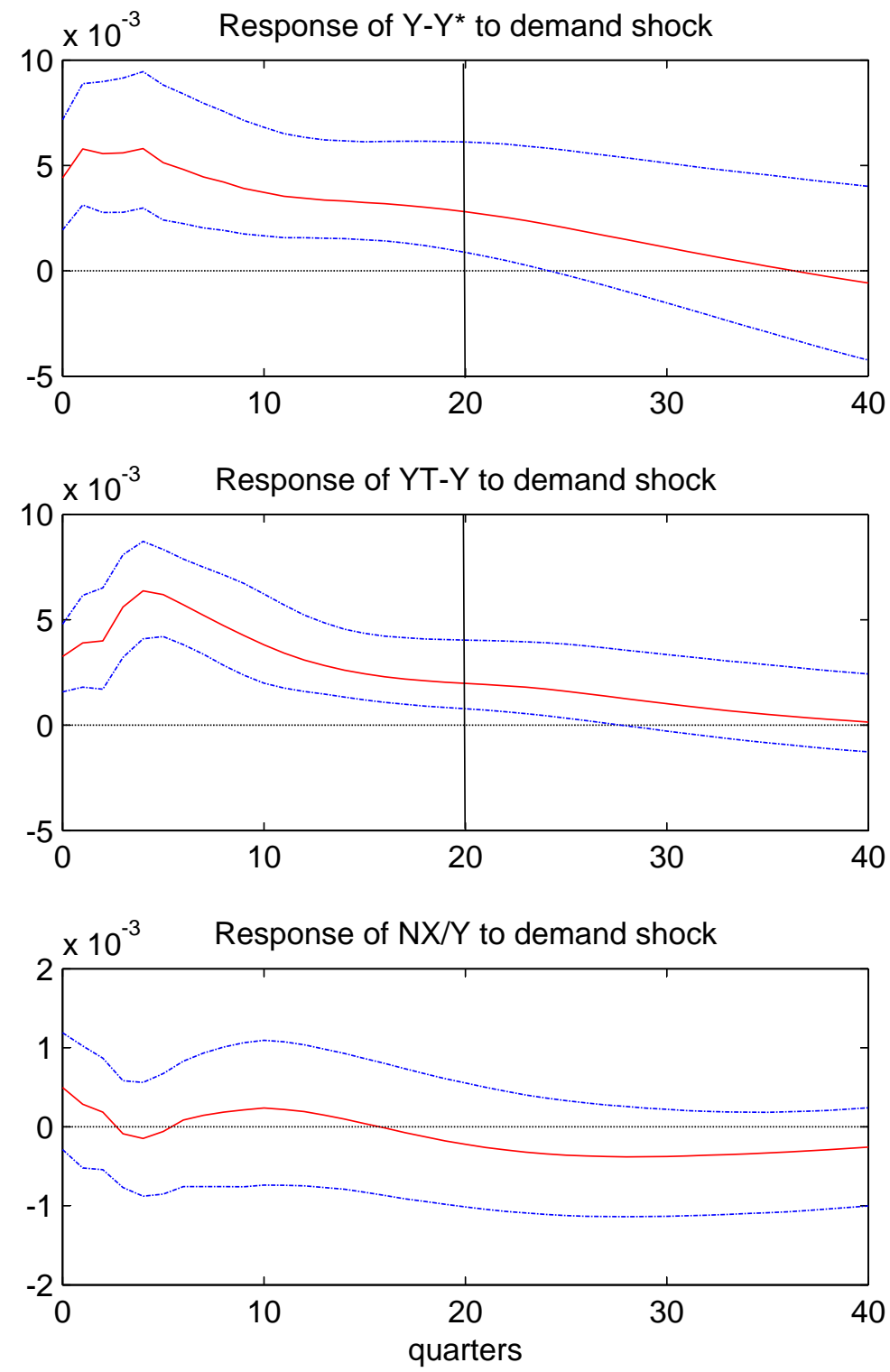
Figure 7
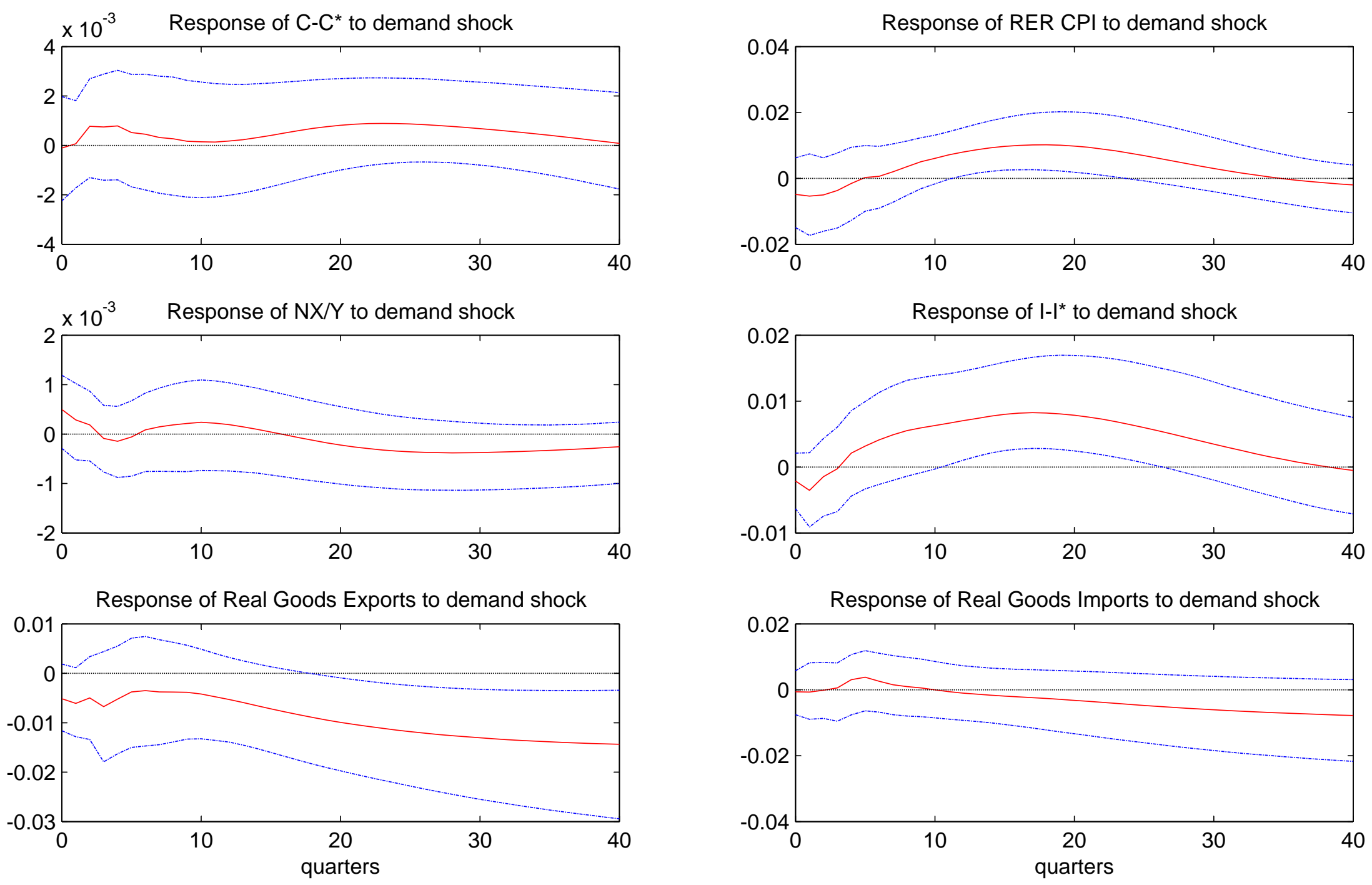
Figure 8
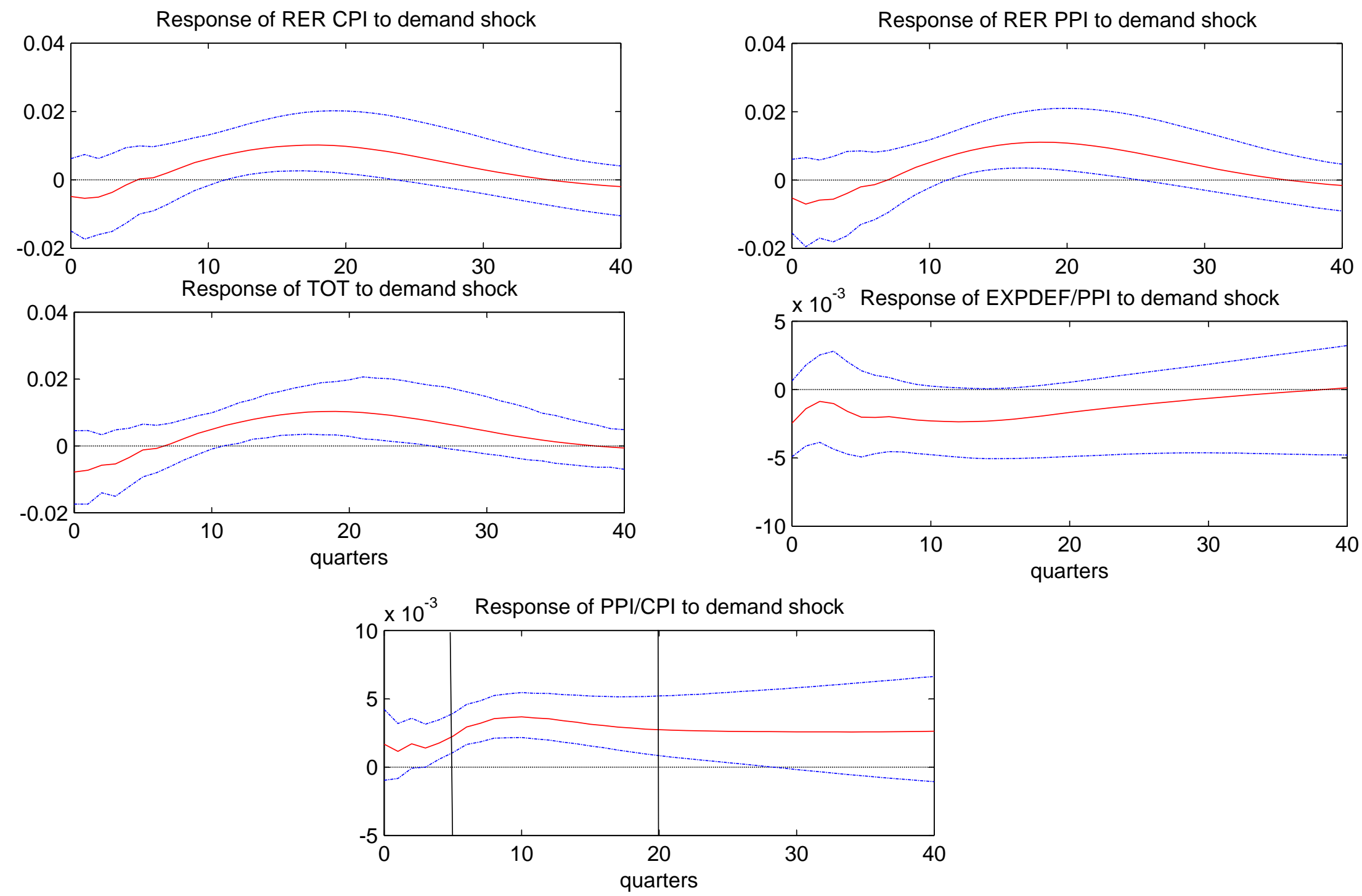
Figure 9
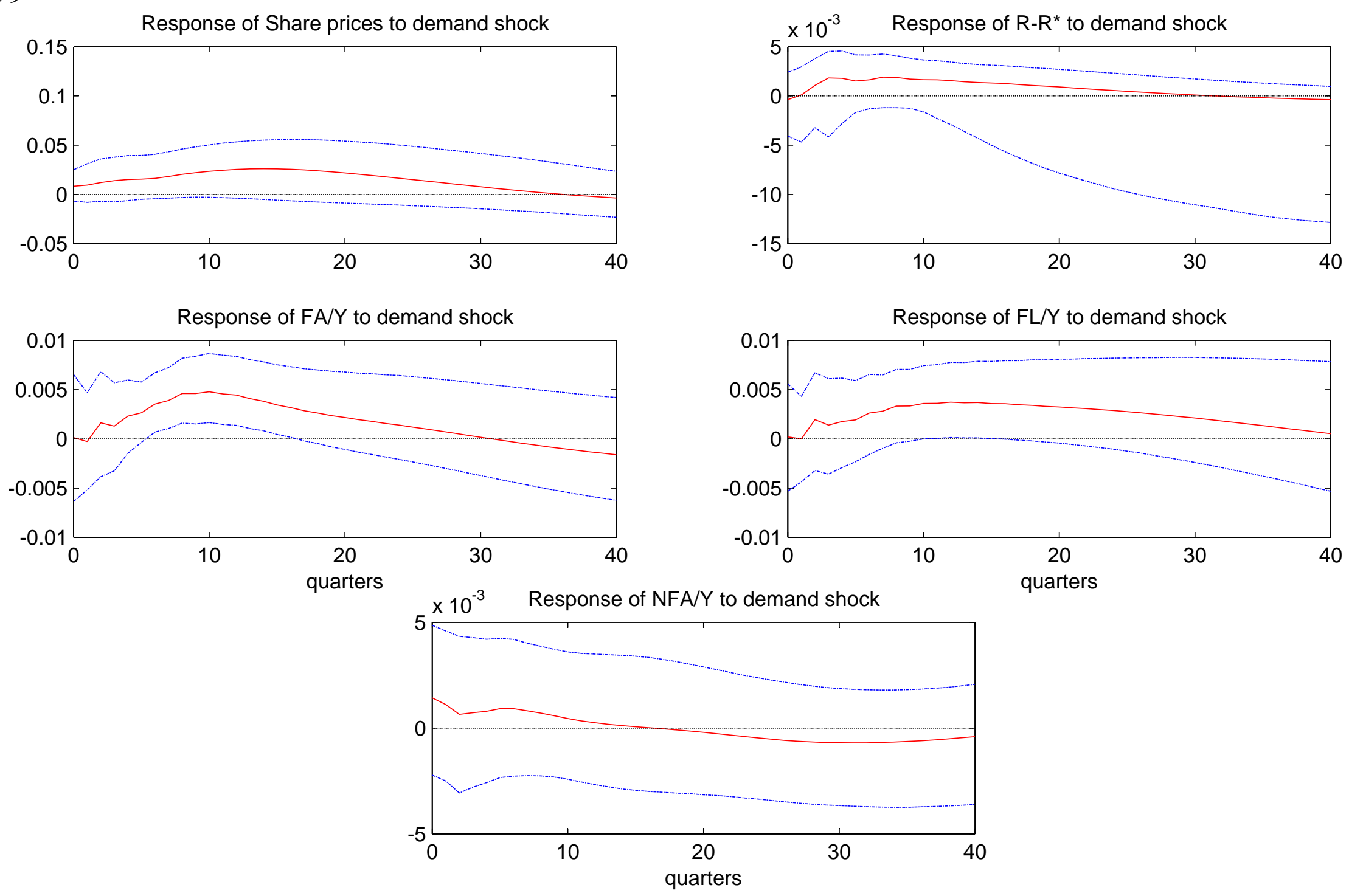

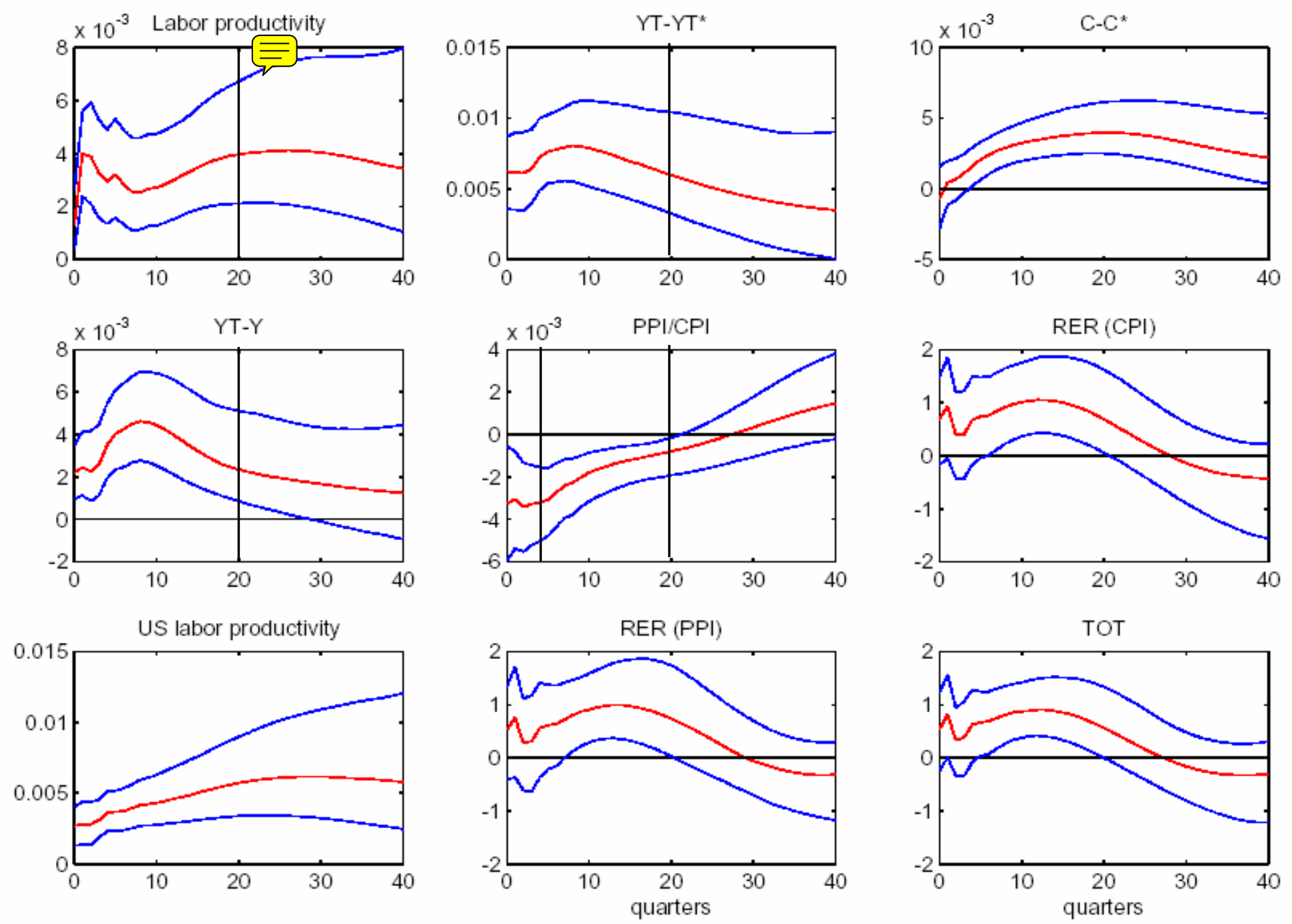
Figure 11
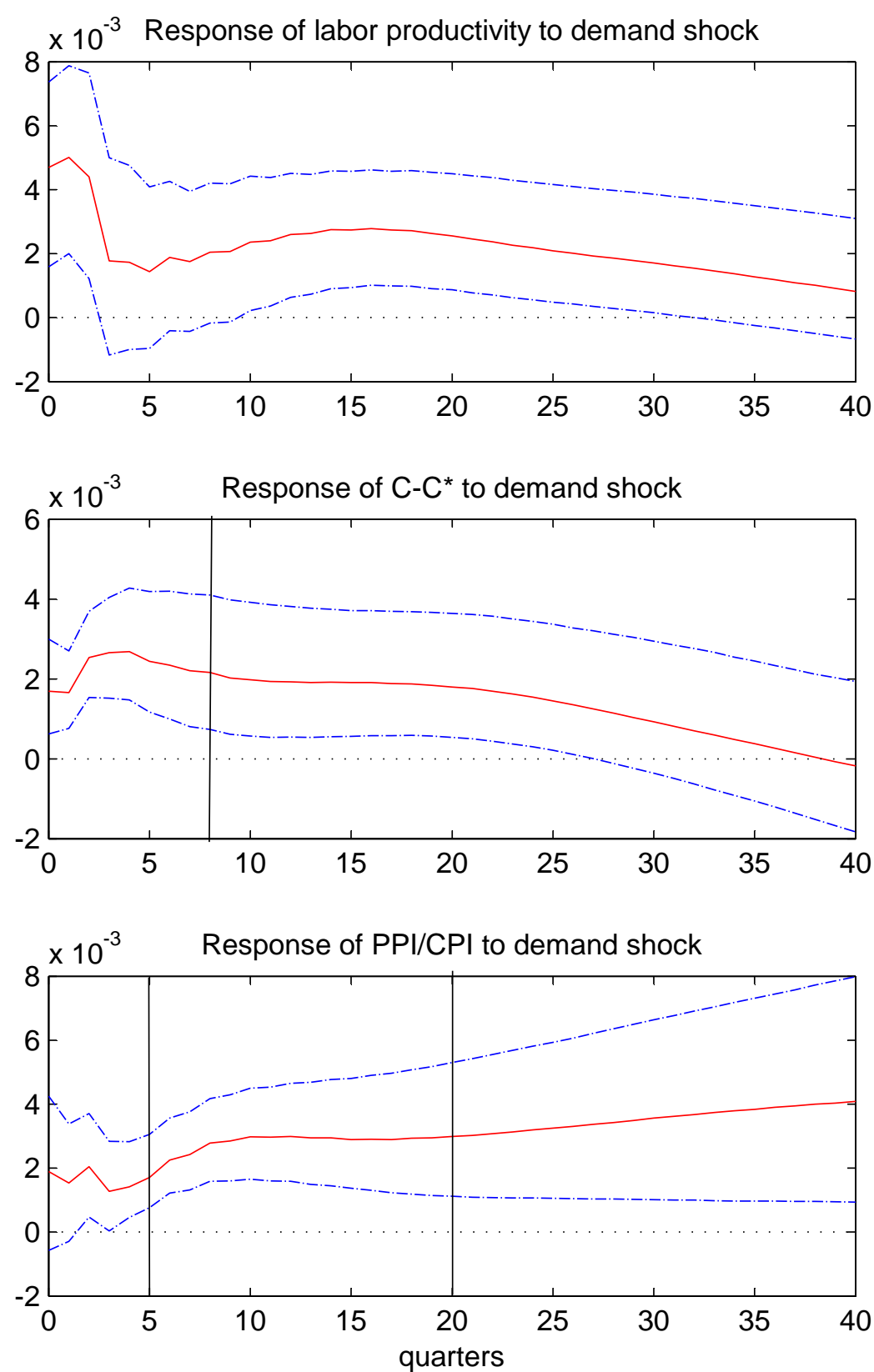
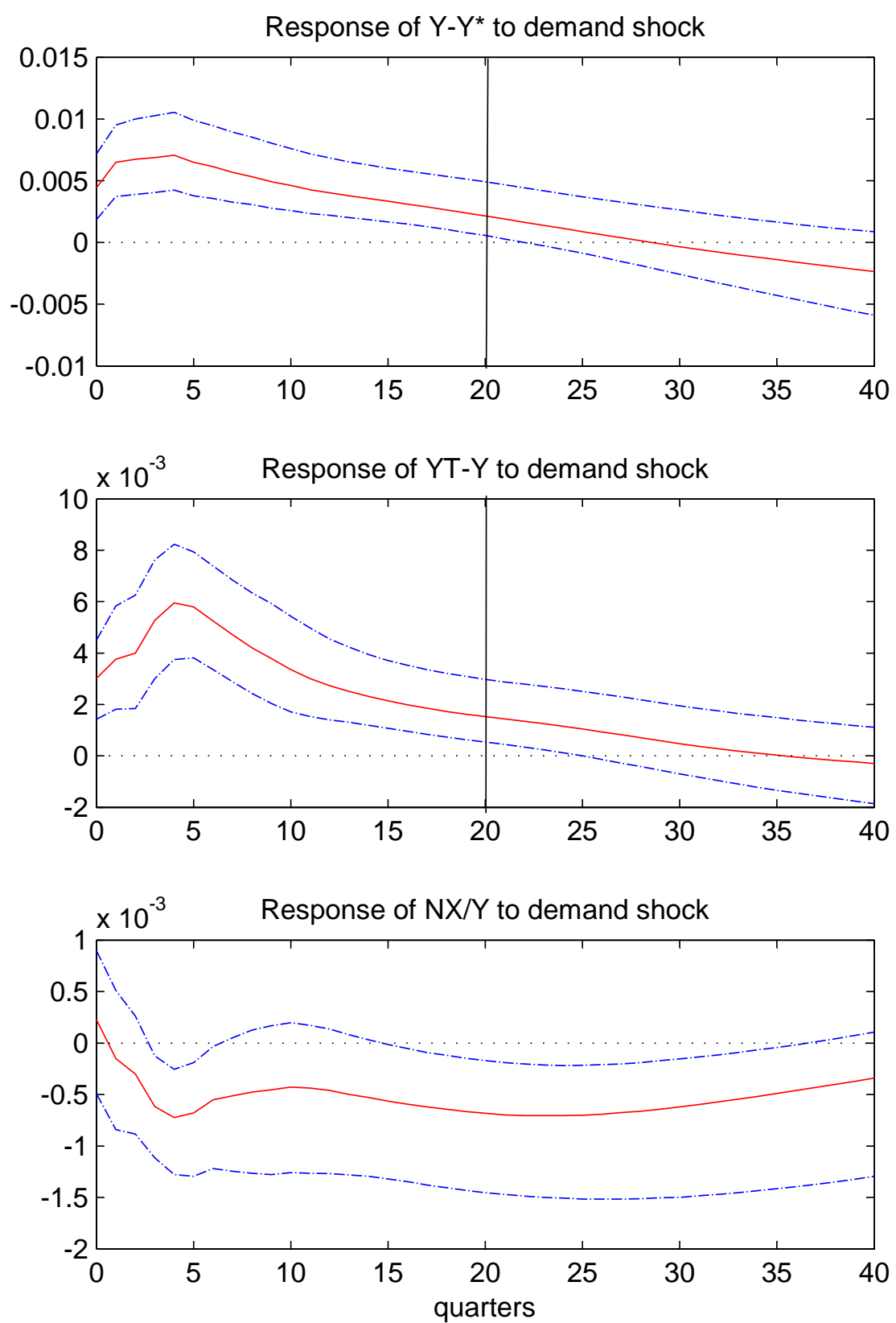
Figure 12
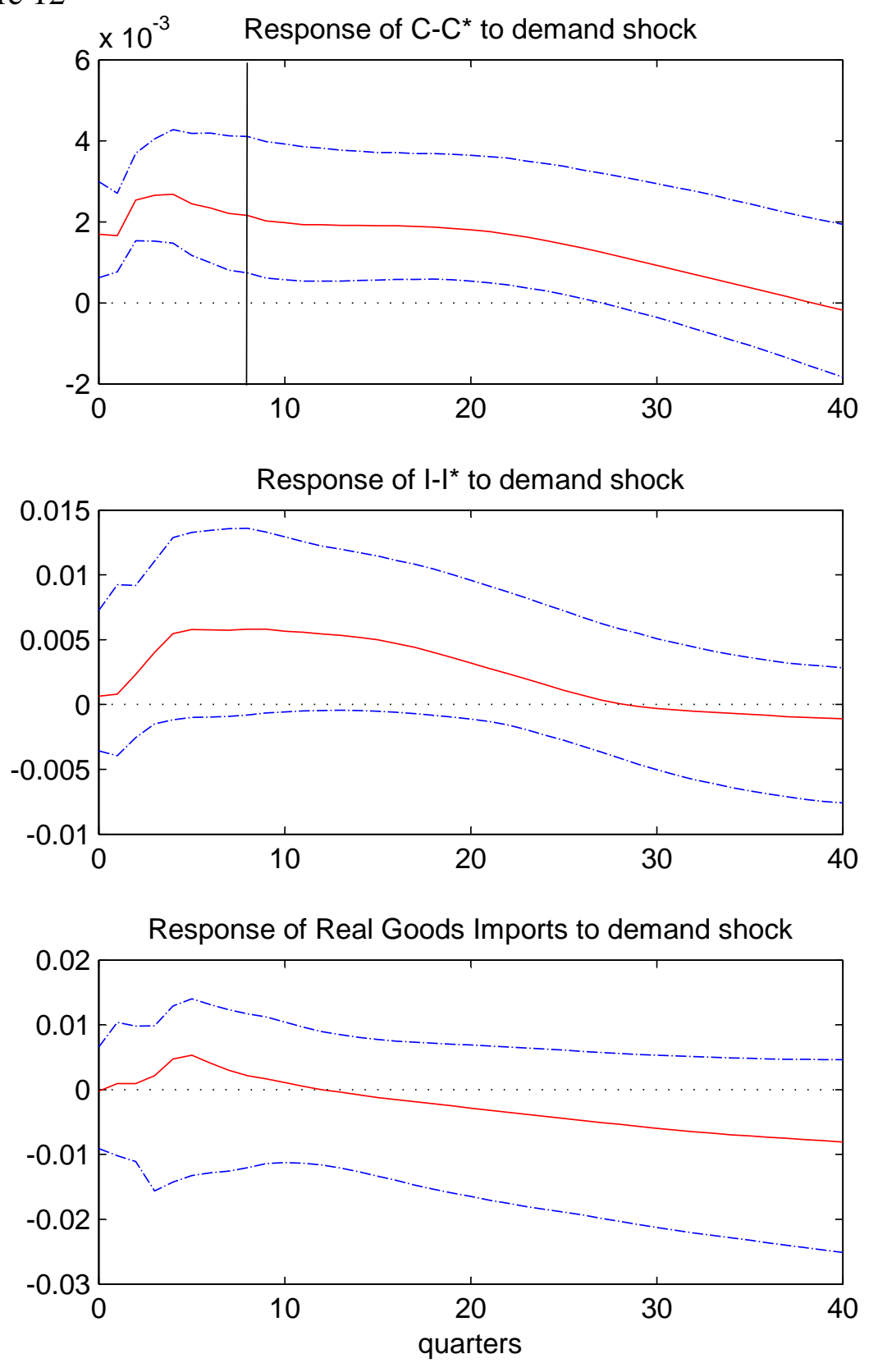
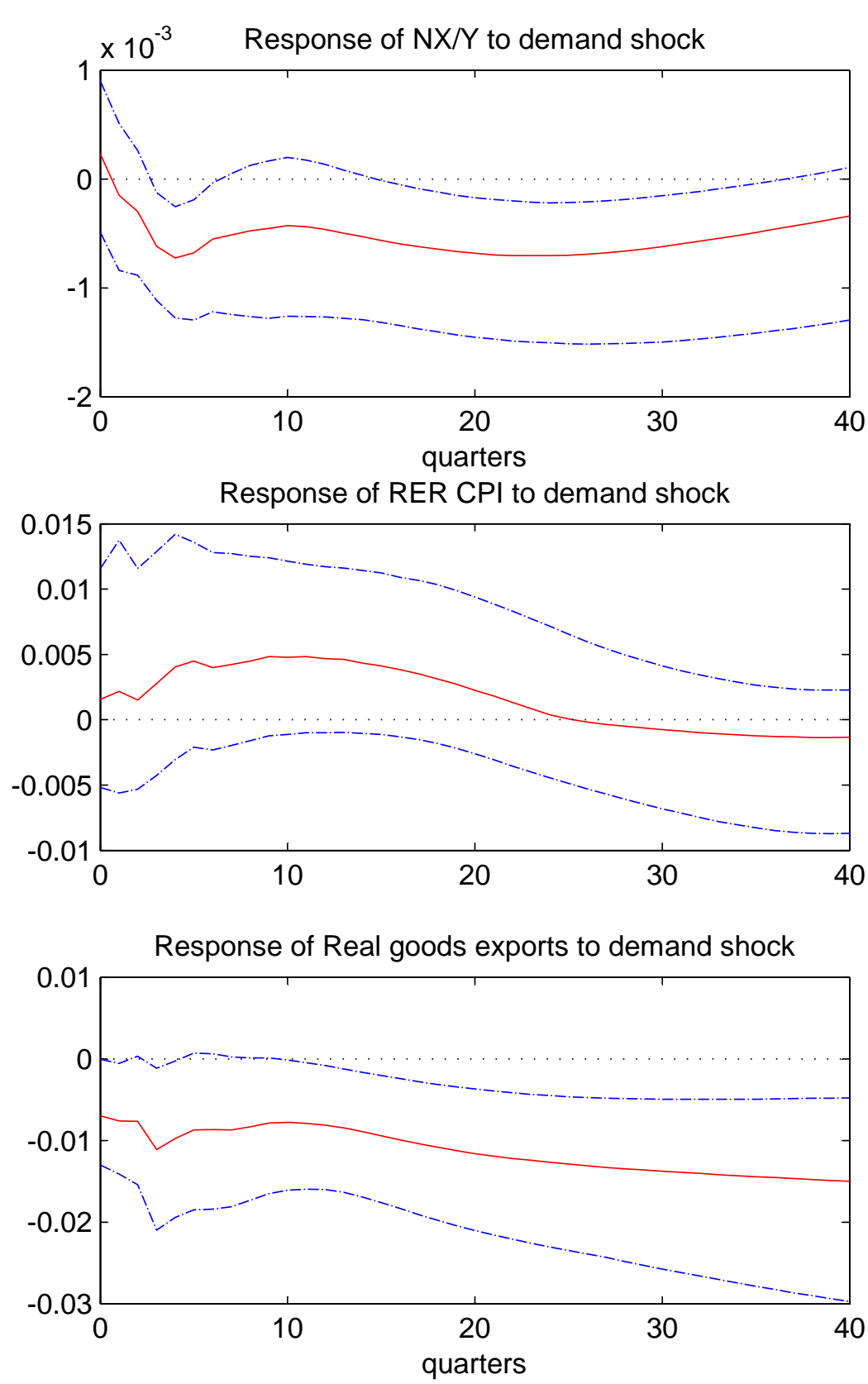